Copyright (C) 2013 IEEE. Personal use of this material is permitted. Permission from IEEE must be obtained for all other uses, in any current or future media, including

reprinting/republishing this material for advertising or promotional purposes, creating new collective works, for resale or redistribution to servers or lists, or reuse of any copyrighted component of this work in other works. 


\title{
Understanding Power Transformer Frequency Response Analysis Signatures
}

\author{
A. Abu-Siada, N. Hashemnia, S. Islam, and Mohammad A.S. Masoum \\ Electrical and Computer Engineering Department, Curtin University, Western Australia
}

\begin{abstract}
SUMMARY
Data obtained using a distributed parameter model to simulate a power transformer are presented. These data could be used in the formulation of standard codes for interpretation of the frequency response analysis signatures of power transformers.
\end{abstract}

Key Words: Power transformer, FRA, condition monitoring, winding deformation.

\section{INTRODUCTION}

THE majority of transformers currently in service worldwide were installed prior to 1980, and consequently most of them are approaching or have already exceeded their design lifetimes $[1,2]$. This poses a significant risk for utilities and other power network stakeholders, since the impact of inservice transformer failure can be catastrophic. One of the most serious problems with an in-service transformer is movement of its windings due to electromagnetic forces generated during short circuit faults. Reduction of clamping pressure due to insulation aging can also cause winding movement, and may result in an explosion [3-6]. There are many causes of mechanical faults, e.g., earthquake, explosion of combustible gas in the transformer oil, short circuit currents, and careless transportation $[7,8]$. While a transformer with minor winding deformation may continue to work satisfactorily, its capability to withstand further mechanical or electrical faults will gradually decrease [9]. Therefore it is essential to detect any minor winding deformation as soon as possible, and to take appropriate remedial action. Winding deformation has various forms, e.g., spiral tightening, conductor tilting, radial/hoop buckling, shorted or open turns, loosened clamping structures, axial displacement, core movement, and collapse of the winding end supports. It is difficult to differentiate between these internal faults using conventional testing methods [10].

In this article data obtained using a high frequency distributed parameter model to simulate a power transformer are presented. Mechanical faults such as axial displacement, radial buckling, disk space variation, loss of clamping, bushing and leakage faults were simulated by modifying the relevant electrical parameters in the transformer model, or by reconfiguring the impacted disks in a $3 \mathrm{D}$ transformer finite element model. It is suggested that the resulting data could be used in the formulation of standard codes for interpretation of the frequency response analysis signatures of power transformers.

\section{FREQUENCY RESPONSE ANALYSIS}

Frequency response analysis (FRA) is a powerful diagnostic technique widely used to identify internal faults within power transformers [11]. Transformer components such as windings, core and insulation can be represented by equivalent circuits comprising resistors, capacitors, and self / mutual inductances, whose values will be altered by a mechanical fault within the transformer. Thus the frequency response of the relevant equivalent circuit winding will change. Changes in ttransformer geometry, or in the dielectric properties of insulating materials due to ageing or increasing water content, also affect the shape of the frequency response, especially the resonant frequencies and their damping [8].

FRA is an offline technique in which a low voltage ac signal is injected at one terminal of a winding, and the response is measured at the other terminal of the same winding with reference to the grounded tank. The FRA analyzer measures the transfer function, impedance or admittance of the winding, typically over the frequency range $10 \mathrm{~Hz}-2 \mathrm{MHz}$, and one or all of these three properties can be used for fault diagnosis. Although the FRA equipment can be connected to the transformer in different ways [12-14], end-to-end connection shown in Fig. 1 is capable of detecting the main types of mechanical faults [14].

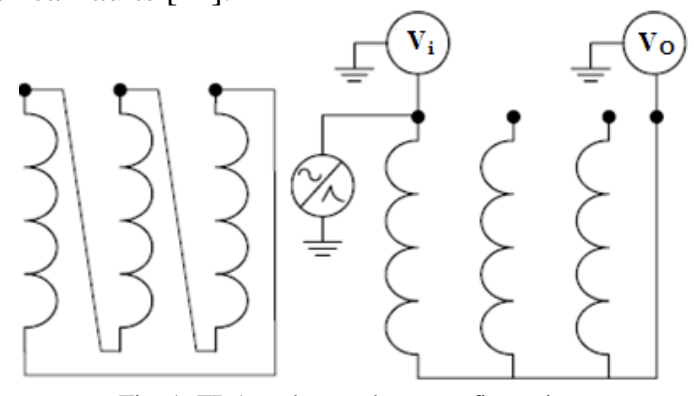

Fig. 1. FRA end-to-end test configuration

The FRA signature is considered as a fingerprint of the transformer, which can be compared with a previous signature in order to detect any mechanical deformation which may have developed between the recording of the two signatures. FRA diagnosis has also been utilized recently to identify winding deformations in rotating machines [13]. While the measurement procedure using commercial test equipment is quite simple, skilled and experienced personnel are required in order to interpret the FRA signatures and identify correctly the type and location of a fault. Although much research has been done on this topic, a reliable FRA signature interpretation code has not yet been published.

The authors of [14] sub-divide the FRA frequency range as follows:

(a) the low frequency range $(<20 \mathrm{kHz})$, within which inductive components dominate the transformer winding response 
(b) the medium frequency range (20-400 kHz), within which the combination of inductive and capacitive components results in multiple resonances

(c) the high frequency range $(>400 \mathrm{kHz})$, within which capacitive components dominate the FRA signature [15]. These ranges and the associated fault types are summarized in Table I [16, 17].

TABLE I

FRA BANDS AND THEIR SENISTIVITY TO FAULTS [16]

\begin{tabular}{|c|c|}
\hline Frequency Band & Fault sensitivity \\
\hline$<20 \mathrm{kHz}$ & $\begin{array}{c}\text { Core deformation, open circuits, shorted turns } \\
\text { and residual magnetism, bulk winding } \\
\text { movement, clamping structure loosening }\end{array}$ \\
\hline $20-400 \mathrm{kHz}$ & Deformation within the main or tap windings \\
\hline$>400 \mathrm{kHz}$ & $\begin{array}{c}\text { Movement of the main and tap windings, } \\
\text { ground impedances variations }\end{array}$ \\
\hline
\end{tabular}

\section{TRANSFormer Model AND Sensitivity ANAlysis}

Simplorer software was used to simulate the transformer model shown in Fig. 2 [17-19].

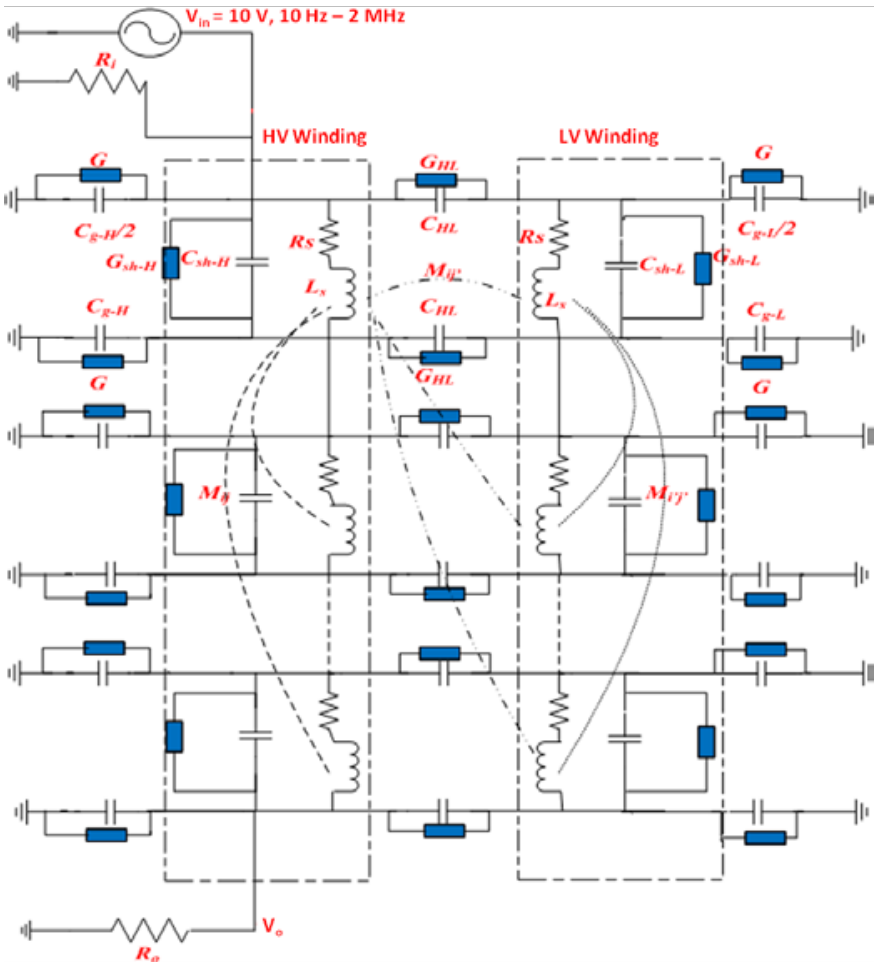

Fig. 2. 10-disk model of a transformer [17].

The high voltage (HV) and low voltage (LV) windings are each assumed to consist of 10 disks. Each disk comprises a series resistance $\left(R_{s}\right)$ and inductance $\left(L_{s}\right)$, shunted by a capacitor $\left(C_{s h}\right)$ and a conductance $\left(G_{s h}\right)$. The capacitance $\left(C_{H L}\right)$ between the $\mathrm{HV}$ and $\mathrm{LV}$ windings is shunted by a dielectric conductance $\left(G_{H L}\right)$, and mutual inductances $\left(M_{i j}\right)$ between coils $i$ and $j$ are included. The dielectric insulation (oil) between the LV winding and the core, and between the $\mathrm{HV}$ winding and the tank, is simulated by a capacitance $\left(C_{g}\right)$ and dielectric conductance $(G)$. The fault-free component values of the model given in [9] and [13] are listed in the Appendix.

In Table II the transformer model parameters, and the mechanical faults which influence them, are listed. Various mechanical faults can be simulated by changing relevant parameters in the transformer model. This can aid in establishing a standard code for FRA signature interpretation.

Table II

MODEL PARAMETERS AND THE MECHANICAL FAULTS WHICH INFLUENCE THEM [9], [11], [17], [20]-[23]

\begin{tabular}{|l|l|}
\hline Model Parameter & Type of Fault \\
\hline Inductance $\mathrm{L}_{\mathrm{s}}$ & $\begin{array}{l}\text { Disk deformation, local breakdown, core } \\
\text { deformation and winding short circuits. }\end{array}$ \\
\hline $\begin{array}{l}\text { Shunt Capacitance } \\
\mathrm{C}_{\mathrm{sh}}\end{array}$ & $\begin{array}{l}\text { Disk movements, buckling due to large } \\
\text { mechanical forces, moisture ingress and loss of } \\
\text { clamping pressure. }\end{array}$ \\
\hline Series Capacitance & $\begin{array}{l}\text { Ageing of insulation, moisture ingress and disk } \\
\text { movement. }\end{array}$ \\
\hline $\mathrm{C}_{\mathrm{HL}}$ & $\begin{array}{l}\text { Shorted or broken disk, failure of caulking } \\
\text { contacts and tap changer contact wear. }\end{array}$ \\
\hline
\end{tabular}

The sensitivity of the FRA signature to variation of the model parameters was investigated. As shown in Fig. 2, a sinusoidal excitation voltage $\left(V_{i n}\right)$ of $10 \mathrm{~V}$ and variable frequency $(10 \mathrm{~Hz}$ to $2 \mathrm{MHz}$ ) is connected to one winding terminal, and the response at the other terminal of the winding $\left(V_{o}\right)$ is recorded. The input/output coaxial leads used in practical measurements are represented by $50 \Omega$ resistors $\left(R_{i}\right.$ and $R_{o}$ in Fig. 2). The transfer function $\mathrm{TF}_{\mathrm{dB}}=20 \log _{10}\left|V_{0}\right|$ $V_{i n} \mid$ is plotted against frequency. Fig. 3 shows the effect of $\pm 10 \%$ changes in the capacitances $C_{g}$ and $C_{s h}$ of the HV winding on the FRA signature, compared to the base line (fingerprint) signature. Increasing $C_{s h}$ decreases the resonance and anti-resonance frequencies, i.e., the local minimum and local maximum frequencies respectively, with small changes in magnitude. Decreasing $C_{s h}$ increases the resonance and antiresonance frequencies. The same trends are observed for $C_{g}$ variation. It will be seen that the impact of varying $C_{g}$ and $C_{s h}$ is more pronounced at frequencies above $400 \mathrm{kHz}$.
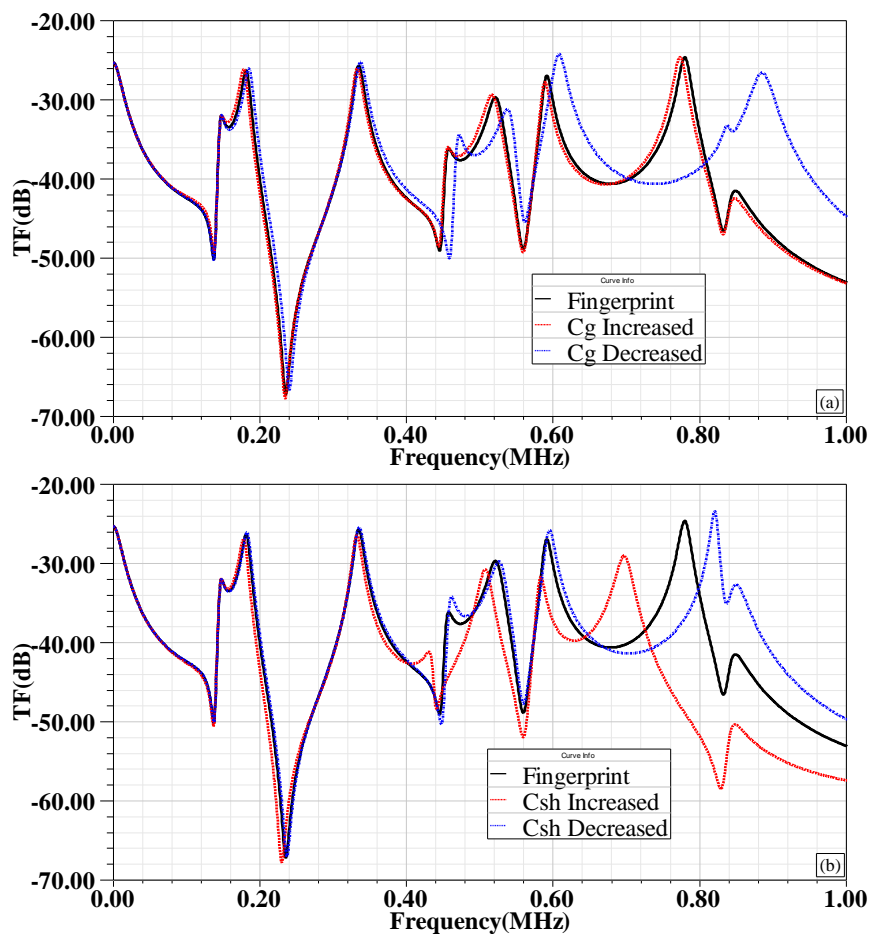

Fig. 3. Effect of $\pm 10 \%$ changes in the HV capacitance on the FRA signature, relative to the baseline (a) $C_{g}$, (b) $C_{s h}$ 
Fig. 4 shows the effect of changing the self $\left(L_{s}\right)$ and mutual $\left(M_{i j}\right)$ inductances by $\pm 10 \%$. Unlike the effect of changes in $C_{g}$ and $C_{s h}$, which appears at frequencies above 400 $\mathrm{kHz}$, the effect of changes in $L_{s}$ and $M_{i j}$ appears below $20 \mathrm{kHz}$ and is more pronounced close to $1 \mathrm{MHz}$. This is attributed to the fact that the amount of magnetic flux penetrating the transformer core at low frequencies is significant, so that the core characteristics affect the FRA signature at low frequency. At high frequencies the magnetic flux tends to encase the core and the transformer capacitive components dominate the response.
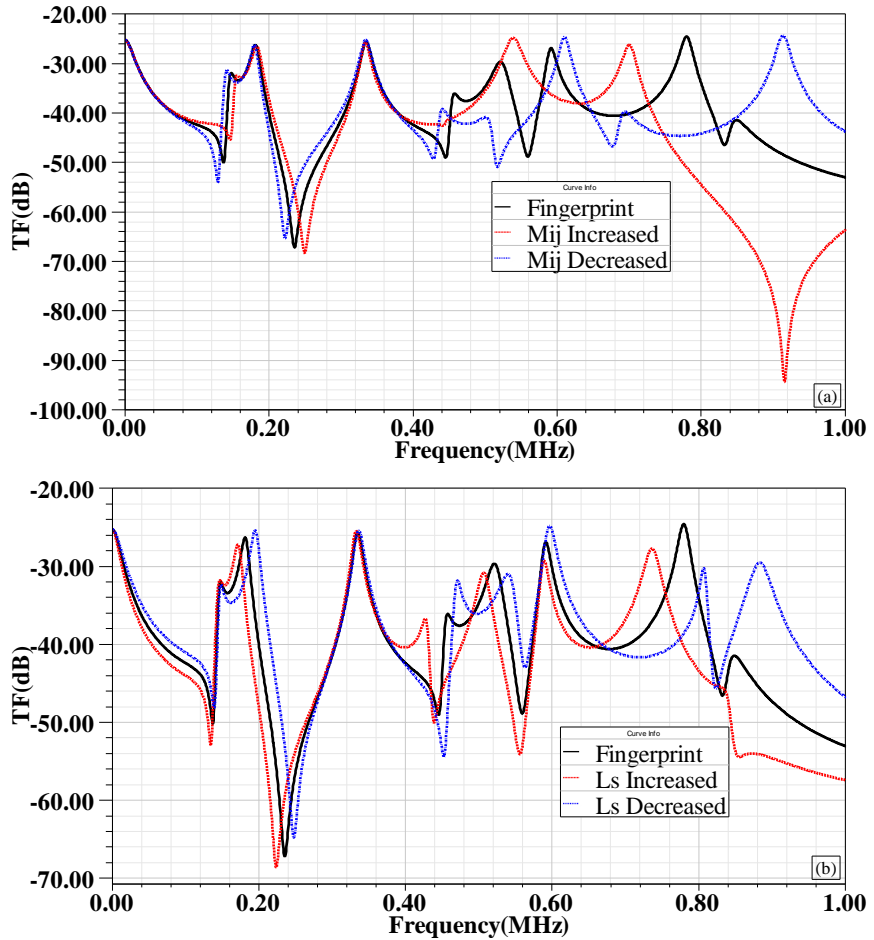

Fig. 4. Effect of $\pm 10 \%$ changes in the HV self/mutual inductances on the FRA signature, relative to the baseline (a) mutual inductance $M_{i j}$ (b) self inductance $L_{S}$

As shown in Fig. 4, increasing $L_{s}$ decreases the resonance and anti-resonance frequencies, with small changes in magnitude. On the other hand, decreasing $L_{s}$ increases the resonance and anti-resonance frequencies, again with small changes in magnitude. Opposite trends are observed when the mutual inductances $M_{i j}$ are changed, i.e., increasing $M_{i j}$ increases the resonance and anti-resonance frequencies, and decreasing $M_{i j}$ decreases them, over the entire frequency range.

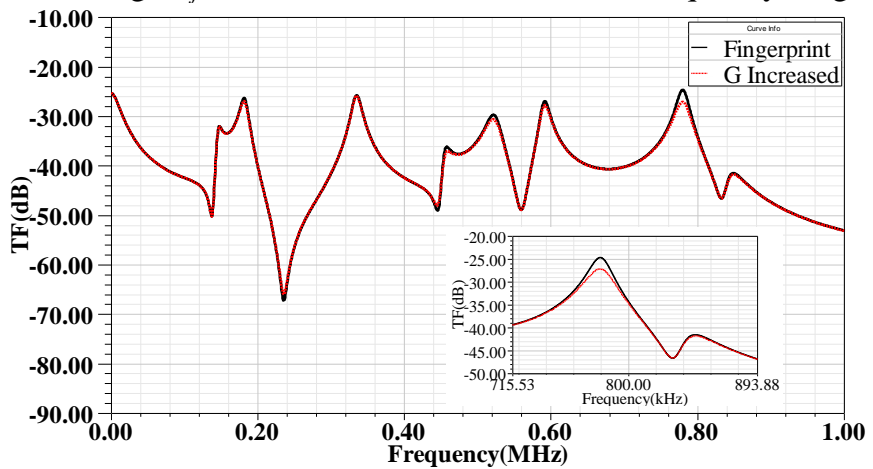

Fig. 5. Effect of increased dielectric conductance $G$ on the FRA signature
Fig. 5 shows the effect increasing the HV conductance $(G)$ by $10 \%$ on the FRA signature (A decrease in conductance, i.e., an increase in dielectric resistance, is considered unlikely for transformer insulation). As shown in Fig. 5, increasing the dielectric conductance $(G)$ has no effect on the resonance and anti-resonance frequencies. It does however slightly change the magnitudes of the peaks at high frequencies. This result is attributed to the very high dielectric resistance used in the simulation (7 M $\Omega$ ), typical for transformer oil.

The effects of $\pm 10 \%$ variations in various electrical parameters on the FRA resonance frequencies and magnitudes are summarised in Table III.

TABLE III

EFFECTS OF $\pm 10 \%$ VARIATIONS IN VARIOUS ELECTRICAL PARAMETERS ON FRA REONANCE FREQUENCIES AND MAGNITUDES (RELATIVE TO FINGERPRINTS)

\begin{tabular}{|c|c|c|c|c|}
\hline \multirow{2}{*}{\multicolumn{2}{|c|}{$\begin{array}{l}\text { Parameter } \\
\text { Variations }\end{array}$}} & \multicolumn{3}{|c|}{ Frequency Range } \\
\hline & & $\begin{array}{c}\text { Low } \\
(<20 \mathrm{kHz})\end{array}$ & $\begin{array}{c}\text { Medium } \\
(20-400 \mathrm{kHz})\end{array}$ & $\begin{array}{c}\text { High } \\
(>400 \mathrm{kHz})\end{array}$ \\
\hline \multirow[b]{2}{*}{$L_{s}$} & $\begin{array}{c}10 \% \\
\text { Increase }\end{array}$ & $\begin{array}{c}\text { Magnitude and } \\
\text { resonance frequencies } \\
\text { decreased }\end{array}$ & $\begin{array}{l}\text { Magnitude and } \\
\text { resonance } \\
\text { frequencies } \\
\text { decreased }\end{array}$ & $\begin{array}{l}\text { Magnitude } \\
\text { and } \\
\text { resonance } \\
\text { frequencies } \\
\text { decreased }\end{array}$ \\
\hline & $\begin{array}{c}10 \% \\
\text { Decrease }\end{array}$ & $\begin{array}{l}\text { Magnitude and } \\
\text { resonance } \\
\text { frequencies } \\
\text { increased }\end{array}$ & $\begin{array}{l}\text { Magnitude and } \\
\text { resonance } \\
\text { frequencies } \\
\text { increased }\end{array}$ & $\begin{array}{l}\text { Magnitude } \\
\text { and } \\
\text { resonance } \\
\text { frequencies } \\
\text { increased }\end{array}$ \\
\hline \multirow{2}{*}{$C_{s h}$} & $\begin{array}{c}10 \% \\
\text { Increase }\end{array}$ & No impact & No impact & $\begin{array}{c}\text { Resonance } \\
\text { frequencies, } \\
\text { magnitude } \\
\text { decreased }\end{array}$ \\
\hline & $\begin{array}{c}10 \% \\
\text { Decrease }\end{array}$ & No impact & No impact & $\begin{array}{c}\text { Resonance } \\
\text { frequencies, } \\
\text { magnitude } \\
\text { increased }\end{array}$ \\
\hline \multirow[b]{2}{*}{$C_{g}$} & $\begin{array}{c}10 \% \\
\text { Increase }\end{array}$ & No impact & No impact & $\begin{array}{c}\text { Resonance } \\
\text { frequencies } \\
\text { slightly } \\
\text { decreased } \\
\end{array}$ \\
\hline & $\begin{array}{c}10 \% \\
\text { Decrease }\end{array}$ & No impact & No impact & $\begin{array}{c}\text { Resonance } \\
\text { frequencies, } \\
\text { magnitude } \\
\text { increased }\end{array}$ \\
\hline \multirow[b]{2}{*}{$M_{i j}$} & $\begin{array}{c}10 \% \\
\text { Increase }\end{array}$ & $\begin{array}{l}\text { Resonance } \\
\text { frequencies } \\
\text { increased } \\
\end{array}$ & $\begin{array}{c}\text { Resonance } \\
\text { frequencies } \\
\text { increased } \\
\end{array}$ & $\begin{array}{l}\text { Resonance } \\
\text { frequencies } \\
\text { increased } \\
\end{array}$ \\
\hline & $\begin{array}{c}10 \% \\
\text { Decrease }\end{array}$ & $\begin{array}{c}\text { Resonance } \\
\text { frequencies } \\
\text { decreased }\end{array}$ & $\begin{array}{c}\text { Resonance } \\
\text { frequencies } \\
\text { decreased }\end{array}$ & $\begin{array}{l}\text { Resonance } \\
\text { frequencies } \\
\text { decreased }\end{array}$ \\
\hline $\boldsymbol{G}$ & $\begin{array}{c}10 \% \\
\text { Increase }\end{array}$ & No impact & No impact & $\begin{array}{l}\text { Magnitude } \\
\text { decreased }\end{array}$ \\
\hline
\end{tabular}

\section{FAULT ANALYSIS}

In order to simulate physical faults within the transformer, Simplorer and Maxwell software were used to simulate a 3D finite element model of the single phase, shell-type transformer shown in Fig. 6.

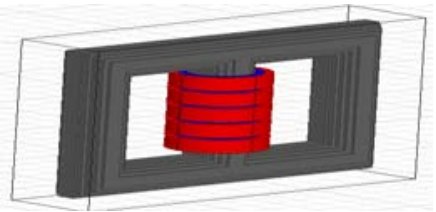

Fig. 6. 3D Transformer model 
Various mechanical faults within the transformer model were simulated by changing the transformer coil configuration. The corresponding changes in the electrical parameters of the transformer model (Fig. 2) were calculated using the software. The resulting signatures were compared with the fingerprint signature.

\section{A. Loss of Clamping Pressure}

Loss of clamping pressure is a common problem, particularly in aged transformers. It is caused by mechanical hysteresis in pressboard and paper insulation [24], and leads to an increase in insulation conductivity because of the reduced insulation thickness between winding layers. It can be simulated by increasing the value of the shunt conductance $G_{s h}$ [21]. Figs. 7 and 8 show the effect of a $20 \%$ increase in $G_{s h}$ on the FRA signatures of the $\mathrm{HV}$ and $\mathrm{LV}$ windings respectively; the resonance and anti-resonance frequencies are not shifted, but the magnitudes of the resonance peaks are decreased over the entire frequency range. The large negative spike in the HV winding signature around $200 \mathrm{kHz}$ is thought to be an artefact of the software.

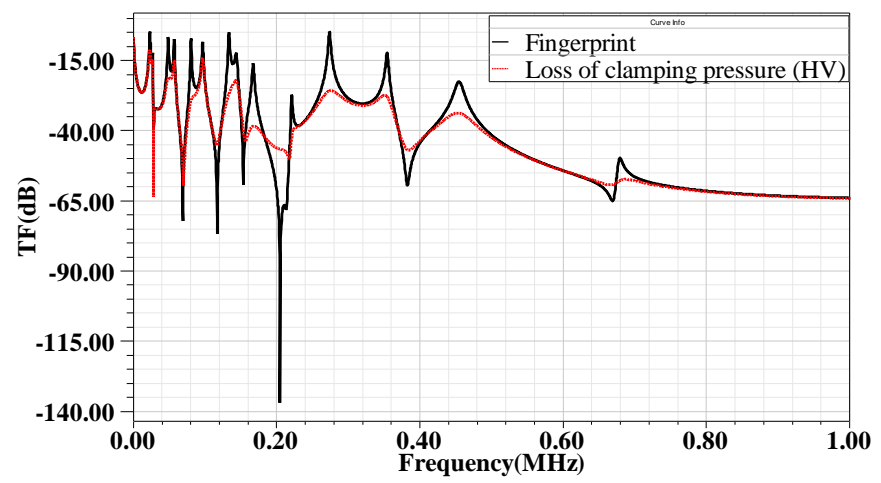

Fig. 7. Effect of simulated loss of clamping pressure on the FRA signature of the $\mathrm{HV}$ winding

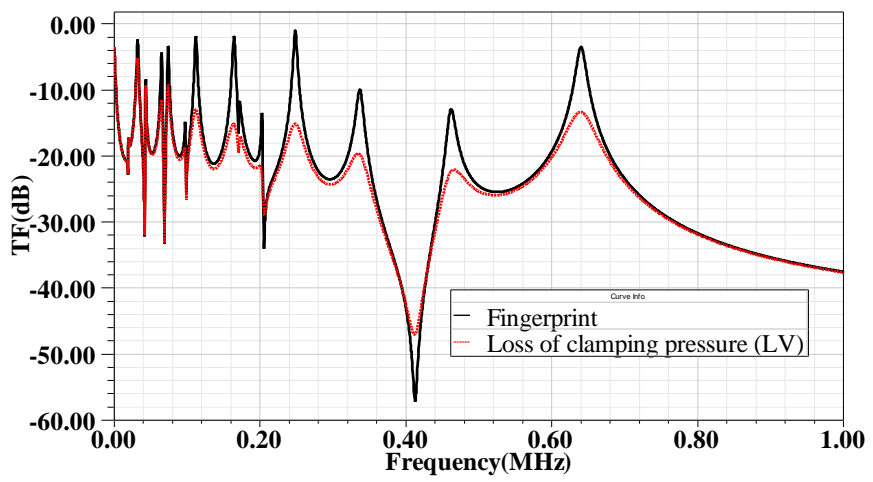

Fig. 8. Effect of simulated loss of clamping pressure on the FRA signature of the $\mathrm{LV}$ winding

\section{B. Inter-Disk Fault}

The inter-disk fault is one of the most common mechanical faults within power transformers, and approximately $80 \%$ of mechanical failures are attributable to it [12]. It is due to changes in the axial disk space (Fig.9) caused by excess mechanical stress and short circuit faults, and can be simulated by increasing the series capacitance $\left(C_{s h}\right)$ and the mutual inductance $\left(M_{i j}\right)$ between the two relevant disks [25, 26]. Fig. 10 shows the effect of a $10 \%$ increase in $\mathrm{C}_{\mathrm{sh}}$ and $\mathrm{M}_{\mathrm{ij}}$ on the $\mathrm{HV}$ FRA signature when the fault occurs at the top, middle and bottom of the $\mathrm{HV}$ winding. A $10 \%$ increase in $C_{\text {sh }}$ and in $M_{i j}$ corresponds to a $10 \%$ increase in $\Delta h$, the space between the affected disks (Fig. 9). Fig. 10 shows that this fault does not have a significant effect on the FRA signature at frequencies below $300 \mathrm{kHz}$. The resonance and anti-resonance frequencies above $300 \mathrm{kHz}$ are decreased, and the peak magnitudes are changed. The frequency decreases are larger when the fault occurs within the top or bottom disks of the winding, rather than within the middle disks.

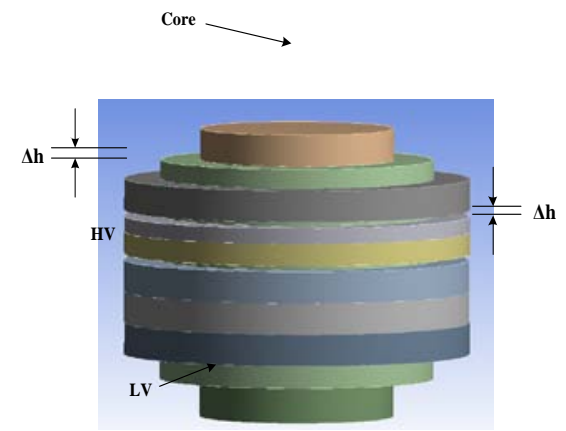

Fig. 9. Interdisk fault $(\Delta \mathrm{h})$ configuration
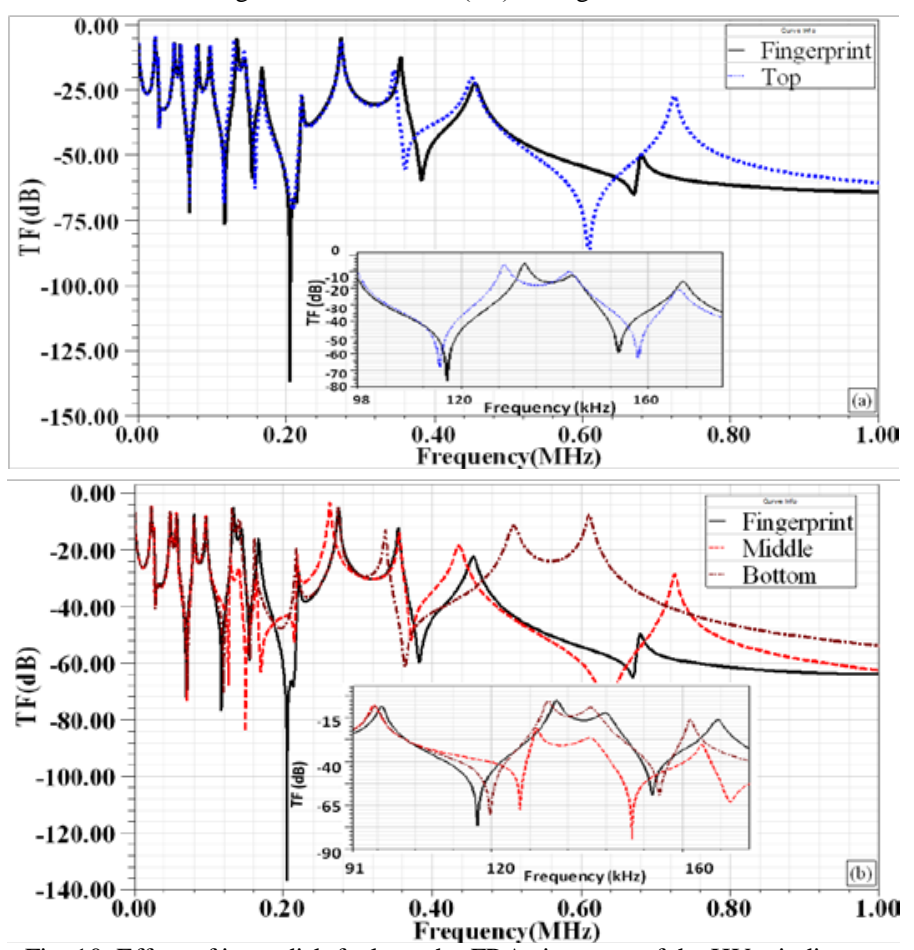

Fig. 10. Effect of inter-disk fault on the FRA signature of the HV winding.

\section{HV Winding Bushing Fault}

This type of fault can be simulated by connecting the bushing T-circuit model shown in Fig. 11 between the voltage source $\mathrm{V}_{\text {in }}$ and the transformer model shown in Fig. 2 [5].

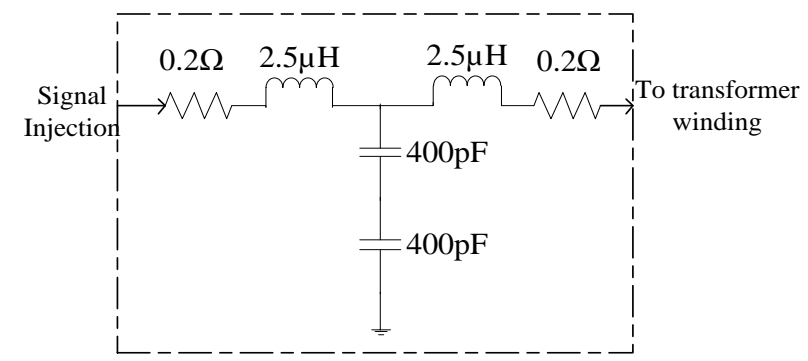

Fig. 11. Transformer bushing model [5] 


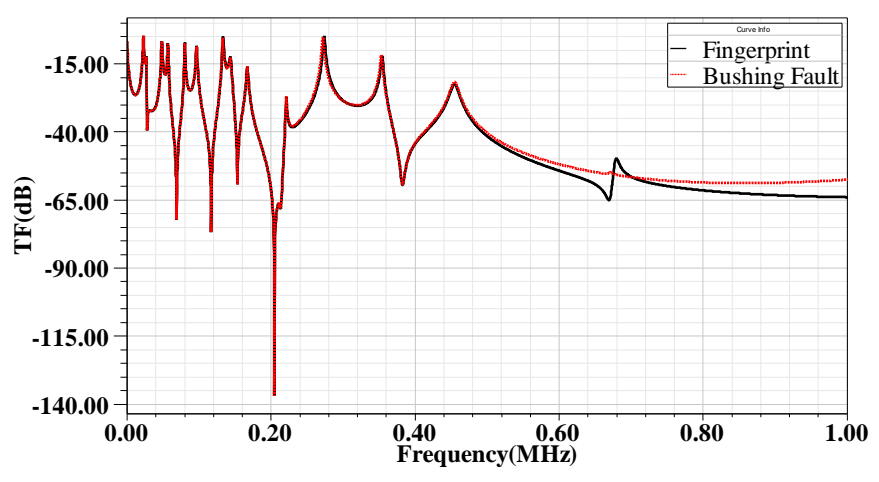

Fig. 12. Impact of high voltage bushing fault on the FRA signature of the HV winding

The effect of a $10 \%$ reduction in bushing capacitance (800 pF) shown in Fig. 11 on the FRA signature is shown in Fig. 12. A reduction in bushing capacitance corresponds to a reduction in the breakdown voltage of the bushing insulation. As shown in Fig. 12, there is no significant change in the signature below $600 \mathrm{kHz}$, but the resonance and antiresonance peaks around $700 \mathrm{kHz}$ in the fingerprint disappear.

\section{Axial Displacement Fault}

This fault occurs due to imbalanced magnetic forces generated in a winding as a result of a short-circuit fault [21]. These forces cause axial movement of the winding as shown in Fig. 13.

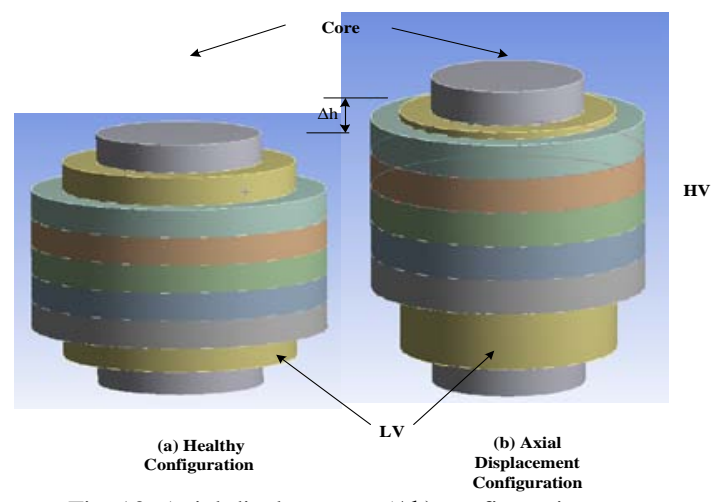

Fig. 13. Axial displacement $(\Delta \mathrm{h})$ configuration

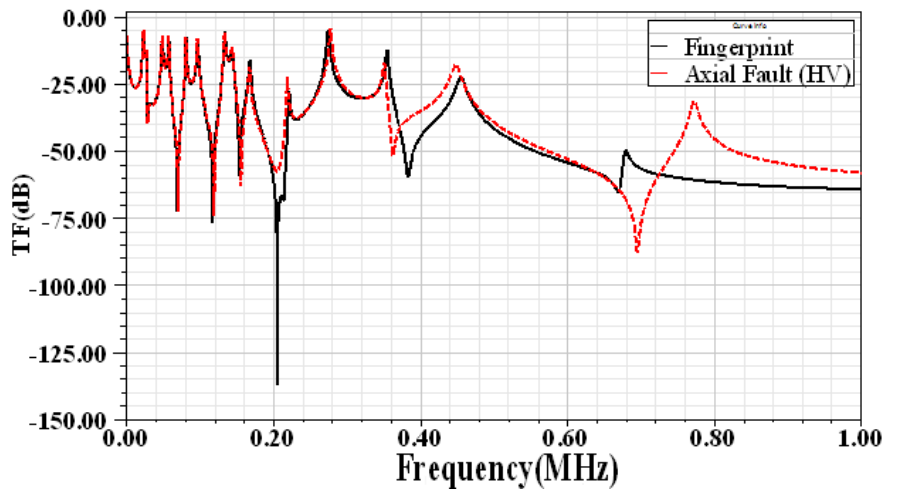

Fig. 14. Impact of HV axial displacement on the FRA signature

The fault can be simulated by changing the values of the series capacitance $\left(C_{\text {sh }}\right)$ and mutual inductance $\left(M_{i j}\right)$ between the $\mathrm{HV}$ and $\mathrm{LV}$ windings [27]. A $10 \%$ increase in $C_{H L}$ and in $M_{i j}$ corresponds to approximately $10 \%$ movement $\Delta \mathrm{h}$ which is the ratio of the HV axial displacement and the overall length of the winding (Fig. 13).

Fig. 14 shows that such a fault has little effect on the FRA signature below $200 \mathrm{kHz}$. In the range $200-400 \mathrm{kHz}$ the resonance frequencies and magnitudes decrease. The resonance around $700 \mathrm{kHz}$ in the fingerprint is shifted towards higher frequency and its magnitude increases. These trends are independent of the direction of the axial movement.

\section{E. Dielectric Leakage Current Fault}

Ground shield damage, oil and paper aging, high moisture content in the winding and abrasion of solid insulation are the main causes of leakage current to earth through transformer insulation [28]. This type of fault can be simulated by increasing the conductance between the HV winding and the ground ( $G$ in Fig.2) [29]. Fig. 15 shows that this fault produces small changes in peak magnitude below $200 \mathrm{kHz}$.

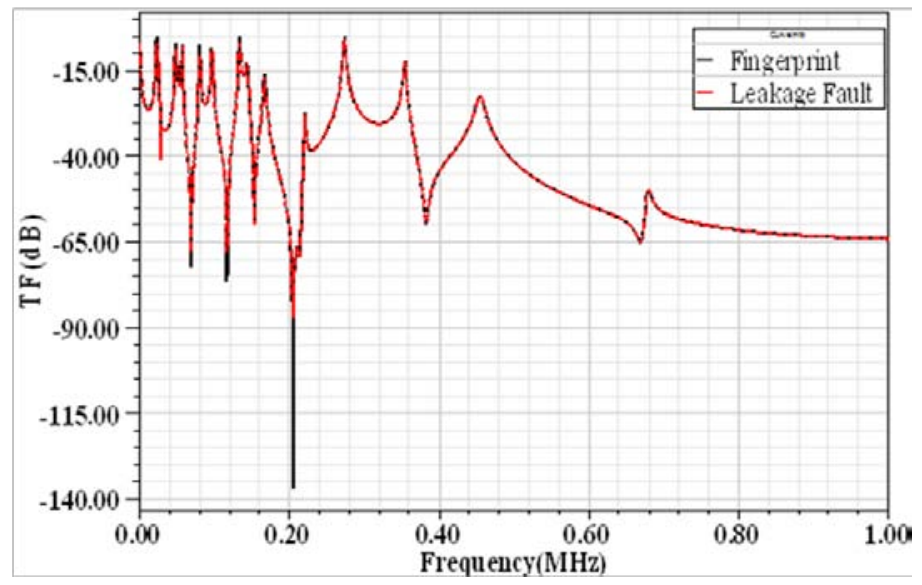

Fig. 15. Effect of leakage fault on the FRA signature

\section{F. Short Circuit Fault}

This fault is due to erosion of the winding and conductor insulation, due to vibrations generated by electromechanical forces. The erosion may lead to excessive current in the winding [27]. The fault can be simulated by short circuiting the series resistance $R_{s}$ and the series inductance $L_{s}$ of the HV winding (Fig.2) [30]. Fig. 16 shows that it fault has little effect on the signature at frequencies below $200 \mathrm{kHz}$. At higher frequencies the magnitude is slightly increased and the resonance frequencies are slightly decreased. The same fault has a greater effect when it occurs at the top or bottom of the winding rather than in the middle.

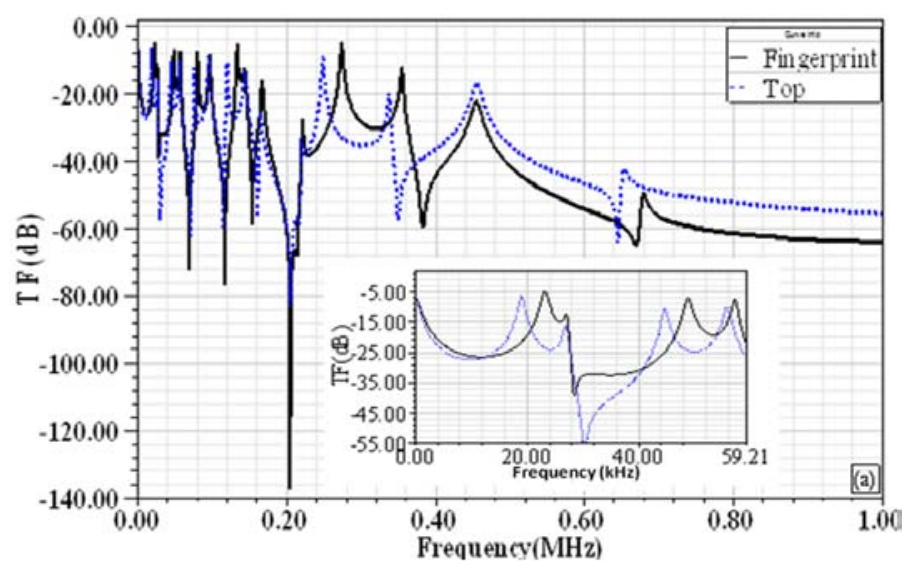




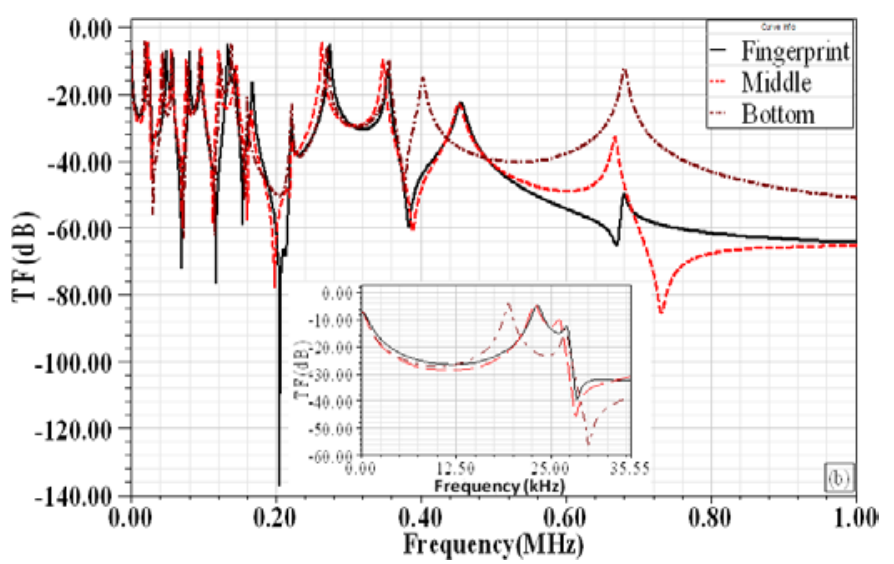

Fig. 16. Impact of $\mathrm{HV}$ winding short circuit fault on the FRA signature when it occurs (a) at the top of the winding, (b) at the middle and bottom of the winding

\section{G. Radial Displacement Fault}

Windings may be subjected to radial forces arising from the interaction of the winding current with the magnetic flux. Fig.17 shows a radial dislocation between the LV and HV windings. Large radial forces may lead to winding buckling [31]. This fault can be simulated by decreasing the capacitance to ground $\left(C_{g}\right)$, the capacitance between the $\mathrm{HV}$ and $\mathrm{LV}$ windings $\left(C_{\mathrm{HL}}\right)$, and the mutual inductance $\left(M_{i j}\right)$ of the impacted disks [32]. A simultaneous decrease of $10 \%$ in each of these three parameters corresponds to a $10 \%$ radial displacement $\Delta \mathrm{w}$ of the impacted disks as shown in Fig. 17. $\Delta \mathrm{w}$ is calculated as the ratio of the radial displacement of the impacted disks to the diameter of the disk. The FRA responses of the $\mathrm{HV}$ and $\mathrm{LV}$ windings are shown in Fig. 18 (a) and (b) respectively.

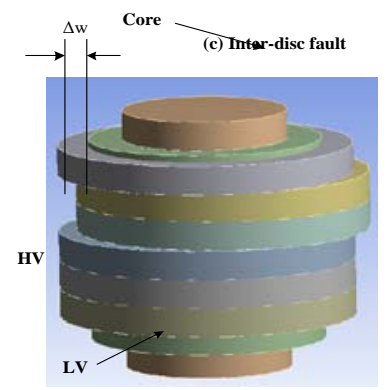

Fig. 17. Radial fault $(\Delta w)$ configuration

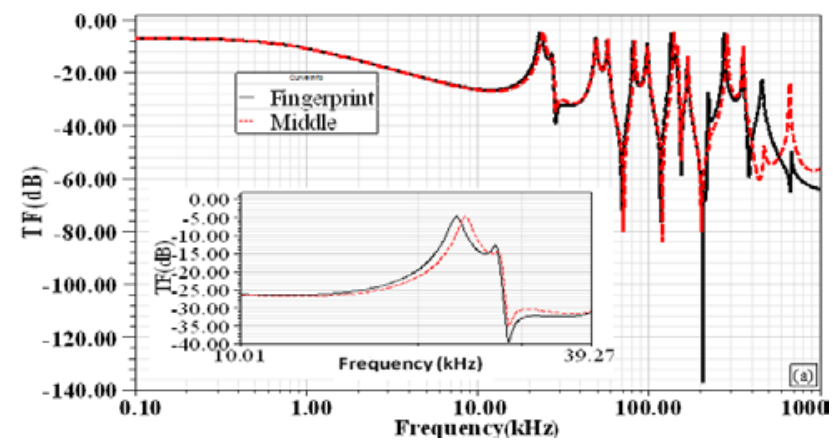

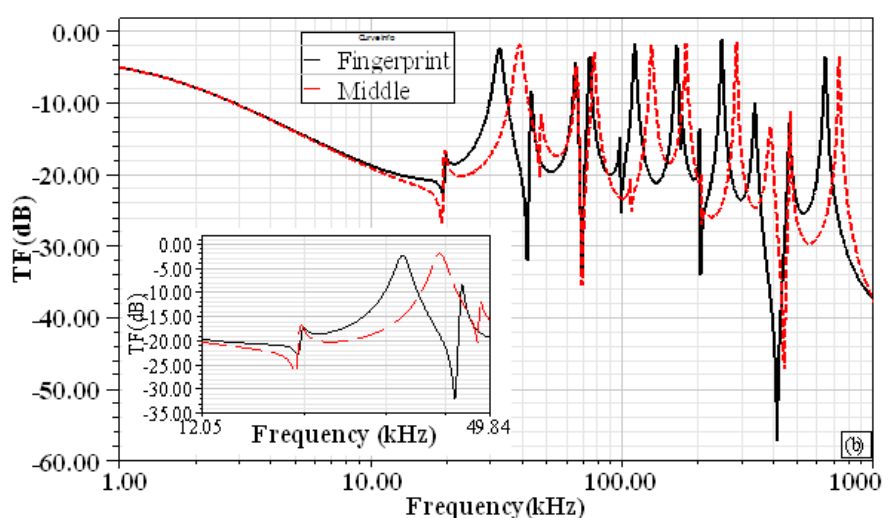

Fig. 18. Impact of radial fault on the FRA signature (a)HV (b) LV winding

Fig. 18 (a) shows that the resonance frequencies of the HV winding are increased slightly at frequencies above $400 \mathrm{kHz}$. In the $\mathrm{LV}$ winding an increase occurs at frequencies above 20 $\mathrm{kHz}$.

Table IV is a listing of the various fault types and their effects on the FRA signature. It could be used in the formulation of standard codes for power transformer FRA signature interpretation.

TABLE IV

IMPACT OF VARIOUS FAULTS ON TRANSFORMER FRA SIGNATURE

\begin{tabular}{|c|c|c|c|}
\hline \multirow{2}{*}{ Fault Type } & \multicolumn{3}{|c|}{ Frequency Range } \\
\hline & $<20 \mathrm{kHz}$ & $20-400 \mathrm{kHz}$ & $>400 \mathrm{kHz}$ \\
\hline $\begin{array}{c}\text { Axial } \\
\text { Displacement }\end{array}$ & No impact & $\begin{array}{c}\text { Resonance } \\
\text { frequencies and } \\
\text { magnitude } \\
\text { decreased }\end{array}$ & $\begin{array}{c}\text { Resonance } \\
\text { frequencies and } \\
\text { magnitude } \\
\text { increased }\end{array}$ \\
\hline $\begin{array}{c}\text { Radial } \\
\text { Displacement }\end{array}$ & $\begin{array}{l}\text { Resonance } \\
\text { frequencies } \\
\text { increased }\end{array}$ & $\begin{array}{l}\text { Resonance } \\
\text { frequencies } \\
\text { increased }\end{array}$ & $\begin{array}{l}\text { Resonance } \\
\text { frequencies } \\
\text { increased }\end{array}$ \\
\hline $\begin{array}{c}\text { High Voltage } \\
\text { Bushing }\end{array}$ & No impact & No impact & $\begin{array}{c}\text { Magnitude } \\
\text { decreased, one } \\
\text { resonance } \\
\text { frequency } \\
\text { disappears }\end{array}$ \\
\hline $\begin{array}{c}\text { Dielectric } \\
\text { Leakage } \\
\text { current }\end{array}$ & $\begin{array}{c}\text { Magnitude } \\
\text { decreased }\end{array}$ & $\begin{array}{l}\text { Magnitude } \\
\text { decreased }\end{array}$ & No impact \\
\hline Inter Disk & $\begin{array}{l}\text { No significant } \\
\text { impact }\end{array}$ & $\begin{array}{c}\text { Resonance } \\
\text { frequencies and } \\
\text { magnitudes } \\
\text { increased }\end{array}$ & $\begin{array}{c}\text { Resonance } \\
\text { frequencies and } \\
\text { magnitudes } \\
\text { increased }\end{array}$ \\
\hline Short Circuit & $\begin{array}{l}\text { No significant } \\
\text { impact }\end{array}$ & $\begin{array}{c}\text { Resonance } \\
\text { frequencies } \\
\text { decreased and } \\
\text { magnitudes } \\
\text { increased } \\
\end{array}$ & $\begin{array}{c}\text { Resonance } \\
\text { frequencies } \\
\text { decreased and } \\
\text { magnitudes } \\
\text { increased } \\
\end{array}$ \\
\hline $\begin{array}{c}\text { Loss of } \\
\text { Clamping } \\
\text { Pressure }\end{array}$ & $\begin{array}{l}\text { Magnitude } \\
\text { decreased }\end{array}$ & $\begin{array}{l}\text { Magnitude } \\
\text { decreased }\end{array}$ & $\begin{array}{l}\text { Magnitude } \\
\text { decreased }\end{array}$ \\
\hline
\end{tabular}

\section{CONCLUSION}

This paper presents a comprehensive analysis of the effects of various faults on the FRA signatures of a transformer simulated by a high frequency model. The faults were simulated through changes in the values of some of the electrical components in the model. It was found that radial displacement of a winding alters the FRA signature over the entire frequency range $(10 \mathrm{~Hz}-1 \mathrm{MHz})$, whereas changes due 
to axial displacement occur only at frequencies above 200 $\mathrm{kHz}$. A table listing various transformer faults and the associated changes in the FRA signature was compiled, and could be used in the formulation of standard codes for power transformer FRA signature interpretation.

\section{APPENDIX}

TRANSFORMER MODEL COMPONENT VALUES [9, 13]

\begin{tabular}{|c|c|c|c|c|c|c|}
\cline { 2 - 7 } \multicolumn{1}{c|}{} & $R_{s}$ & $L_{s}$ & $C_{s h}$ & $C_{g}$ & $C_{h l}$ & $1 / G$ \\
\hline $\mathrm{HV}$ & $1.2 \Omega$ & $180 \mu \mathrm{H}$ & $0.013 \mathrm{nF}$ & $3 \mathrm{nF}$ & $5 \mathrm{nF}$ & $7 \mathrm{M} \Omega$ \\
\hline $\mathrm{LV}$ & $0.5 \Omega$ & $65 \mu \mathrm{H}$ & $0.026 \mathrm{nF}$ & $6 \mathrm{nF}$ & $5 \mathrm{Nf}$ & $7 \mathrm{M} \Omega$ \\
\hline
\end{tabular}

\section{REFERENCES}

[1] S. Islam, K. M. Coates, and G. Ledwich, "Identification of high frequency transformer equivalent circuit using Matlab from frequency domain data," in Industry Applications Conference, 1997. Thirty-Second IAS Annual Meeting, IAS '97., Conference Record of the 1997 IEEE, 1997, pp. 357-364 vol.1.

[2] E.J. Figueroa,"Managing An Aging Fleet of Transformers," Canada, 2009. [3]L. M. Geldenhuis, "Power transformer life management," in Electricity Distribution, 2005. CIRED 2005. 18th International Conference and Exhibition on, 2005, pp. 1-4.

[4]S. M. Islam and G. Ledwich, "Locating transformer faults through sensitivity analysis of high frequency modeling using transfer function approach," in Electrical Insulation, 1996., Conference Record of the 1996 IEEE International Symposium on, 1996, pp. 38-41 vol.1.

[5]M. Wang, A. J. Vandermaar, and K. D. Srivastava, "Improved detection of power transformer winding movement by extending the FRA high frequency range," Power Delivery, IEEE Transactions on, vol. 20, pp. 1930-1938, 2005.

[6]W. J. McNutt, W. M. Johnson, R. A. Nelson, and R. E. Ayers, "Power Transformen Short-Circuit Strength - Requirements, Design, and Demonstration," Power Apparatus and Systems, IEEE Transactions on, vol. PAS-89, pp. 1955-1969, 1970.

[7]M. Bagheri, M. S. Naderi, T. Blackburn, and T. Phung, "FRA vs. short circuit impedance measurement in detection of mechanical defects within large power transformer," in Electrical Insulation (ISEI), Conference Record of the 2012 IEEE International Symposium on, 2012, pp. 301-305.

[8]K. G. N. B. Abeywickrama, Y. V. Serdyuk, and S. M. Gubanski, "Exploring possibilities for characterization of power transformer insulation by frequency response analysis (FRA)," Power Delivery, IEEE Transactions on, vol. 21, pp. 1375-1382, 2006.

[9]E. Rahimpour, M. Jabbari, and S. Tenbohlen, "Mathematical Comparison Methods to Assess Transfer Functions of Transformers to Detect Different Types of Mechanical Faults," Power Delivery, IEEE Transactions on, vol. 25, pp. 2544-2555, 2010.

[10]B. J. Small and A. Abu-Siada, "A new method for analysing transformer condition using frequency response analysis," in Power and Energy Society General Meeting, 2011 IEEE, 2011, pp. 1-5.

[11]S. D. Mitchell and J. S. Welsh, "Modeling Power Transformers to Support the Interpretation of Frequency-Response Analysis," Power Delivery, IEEE Transactions on, vol. 26, pp. 2705-2717, 2011.

[12]E. Rahimpour, J.Christian, K. Feser, H. Mohseni, "Transfer Function Method to Diagnose Axial Displacement, Radial Deformation of Transformer Winding," Power Engineering Review, IEEE, vol.22, pp.70-70, 2002.

[13] C. A. Platero, F. Blazquez, P. Frias, and D. Ramirez,"Influence of Rotor Position in FRA Response for Detection of Insulation Failures in Salient-Pole Synchronous Machines," IEEE Transactions on Energy Conversion, vol. 26, pp. 671-676, June 2011.

[14]E. P. Dick and C. C. Erven, "Transformer Diagnostic Testing by Frequuency Response Analysis," Power Apparatus and Systems, IEEE Transactions on, vol. PAS-97, pp. 2144-2153, 1978.

[15]W. Zhongdong, L. Jie, and D. M. Sofian, "Interpretation of Transformer FRA Responses\&\#x2014; Part I: Influence of Winding Structure," Power Delivery, IEEE Transactions on, vol. 24, pp. 703-710, 2009.

[16]A. Shintemirov, W. H. Tang, and Q. H. Wu, "Transformer winding condition assessment using frequency response analysis and evidential reasoning," Electric Power Applications, IET, vol. 4, pp. 198-212, 2010.

[17]E. Rahimpour, J. Christian, K. Feser, H. Mohseni,"Transfer function method to diagnose axial displacement and radial deformation of transformer windings," Power Delivery, IEEE Transactions on, vol. 18, pp.493-505, 2003. [18]L. Satish and S. K. Sahoo, "An effort to understand what factors affect the transfer function of a two-winding transformer," Power Delivery, IEEE Transactions on, vol. 20, pp. 1430-1440, 2005.
[19]K. Ragavan and L. Satish, "Localization of Changes in a Model Winding Based on Terminal Measurements: Experimental Study," Power Delivery, IEEE Transactions on, vol. 22, pp. 1557-1565, 2007.

[20]A. Shintemirov, W. H. Tang, and Q. H. Wu, "Transformer Core Parameter Identification Using Frequency Response Analysis," Magnetics, IEEE Transactions on, vol. 46, pp. 141-149, 2010.

[21]A. Abu-siada and S. Islam, "A Novel Online Technique to Detect Power Transformer Winding Faults," Power Delivery, IEEE Transactions on, vol. 27, pp. 849-857, 2012.

[22]A. A. Reykherdt and V. Davydov, "Case studies of factors influencing frequency response analysis measurements and power transformer diagnostics," Electrical Insulation Magazine, IEEE, vol. 27, pp. 22-30, 2011.

[23]N. Abeywickrama, Y. V. Serdyuk, and S. M. Gubanski, "High-Frequency Modeling of Power Transformers for Use in Frequency Response Analysis (FRA)," Power Delivery, IEEE Transactions on, vol. 23, pp. 2042-2049, 2008. [24]G. Junfeng, G. Wensheng, T. Kexiong, and G. Shengyou, "Deformation analysis of transformer winding by structure parameter," in Properties and Applications of Dielectric Materials, 2003. Proceedings of the 7th International Conference on, 2003, pp. 487-490 vol.1.

[25]D. M. Sofian, W. Zhongdong, and L. Jie, "Interpretation of Transformer FRA Responses\&\#x2014; Part II: Influence of Transformer Structure," Power Delivery, IEEE Transactions on, vol. 25, pp. 2582-2589, 2010.

[26]E. Rahimpour, S. Tenbohlen, "Experimental and theoretical investigation of disc space variation in real high-voltage windings using transfer function method," Electric Power Applications, IET, vol. 4, pp. 451-461, 2010.

[27] M.R.Barzegaran, "Detecting the Position of Winding Short Circuit Faults in Transformer using High Frequency Analysis," European Journal of Scientific Research ISSN 1450-216X Vol.23 No.4 (2008), pp.644-658, 2008

[28]N. Abeywickrama, Y. V. Serdyuk, and S. M. Gubanski, "Effect of Core Magnetization on Frequency Response Analysis (FRA) of Power Transformers," Power Delivery, IEEE Transactions on, vol. 23, pp. 14321438,2008

[29]J. Chong and A. Abu-Siada, "A novel algorithm to detect internal transformer faults," in Power and Energy Society General Meeting, 2011 IEEE, 2011, pp. 1-5.

[30]J. Bak-Jensen, B. Bak-Jensen, and S. D. Mikkelsen, "Detection of faults and ageing phenomena in transformers by transfer functions," Power Delivery, IEEE Transactions on, vol. 10, pp. 308-314, 1995.

[31]K. Pourhossein, G. B. Gharehpetian, and E. Rahimpour, "Buckling severity diagnosis in power transformer windings using Euclidean Distance classifier," in Electrical Engineering (ICEE), 2011 19th Iranian Conference on, 2011, pp. 1-1.

[32]W. H. Tang, A. Shintemirov, and Q. H. Wu, "Detection of minor winding deformation fault in high frequency range for power transformer," in Power and Energy Society General Meeting, 2010 IEEE, 2010, pp. 1-6.

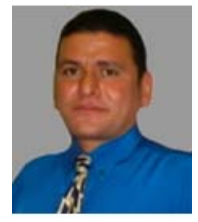

A. Abu-Siada (M’07, SM'12) received his B.Sc. and M.Sc degrees from Ain Shams University, Egypt and the $\mathrm{PhD}$ degree from Curtin University, Australia, all in Electrical Engineering. Currently he is a Senior Lecturer in the Department of Electrical and Computer Engineering at Curtin University. His research interests include power system stability, condition monitoring, power electronics and power quality. He is Editor-in-Chief of the international journal Electrical and Electronic Engineering, a regular reviewer for IEEE Transactions on Dielectrics and Electrical Insulation, Power Electronics and Sustainable Energy. He is the vice-chair of the IEEE Computation Intellegence Society, WA Chapter.

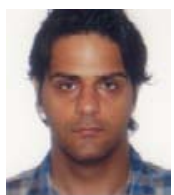

N. Hashemnia received BSc in Electrical Power Engineering from Yazd University, Iran in 2006 and Master of Electrical Utility Engineering from Curtin University in 2010. He received a scholarship from the Cooperative Research Centre for Infrastructure and Asset Management in August 2011, to enable him to pursue his $\mathrm{PhD}$ study at Curtin University. His research interests include power transformer condition monitoring and application of artificial intelligence to power systems.

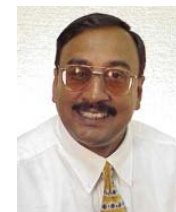

S. Islam (M’83, SM’93) received the B.Sc. from Bangladesh University of Engineering and Technology, Bangladesh, and the M.Sc. and PhD degrees from King Fahd University of Petroleum and Minerals, Saudi Arabia, all in electrical power engineering, in 1979, 1983, and 1988 respectively. He is currently the Chair Professor in Electrical Power Engineering at Curtin University, Australia. He received the IEEE T 
Burke Haye Faculty Recognition award in 2000. His research interests are in condition monitoring of transformers, wind energy conversion and power systems. He is a regular reviewer for the IEEE Transactions on Energy Conversion, Power Systems and Power Delivery. Prof. Islam is an Editor of the IEEE Transaction on Sustainable Energy.

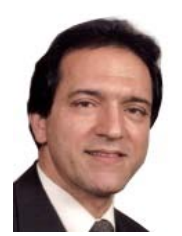

Mohammad A. S. Masoum (S'88-M'91-SM'05) received his B.S., M.S. and Ph.D. degrees in Electrical and Computer Engineering in 1983, 1985, and 1991, respectively, from the University of Colorado, USA. Dr. Masoum's research interests include optimization, power quality and stability of power systems/electric machines and distributed generation. Currently, he is a Professor and the Discipline Leader and Course Coordinator for Power System Engineering in the Electrical and Computer Engineering Department, Curtin University, Australia. He is the coauthor of Power Quality in Power Systems and Electrical Machines (Elsevier, 2008) and Power Conversion of Renewable Energy Systems (Springer, 2011). Dr. Masoum is Editor-in-Chief for the American Journal of Engineering and Applied Science, and an editor of the Australian Journal of Electrical \& Electronic Engineering. 


\title{
Understanding Power Transformer Frequency Response Analysis Signatures
}

\author{
A. Abu-Siada, N. Hashemnia, S. Islam, and Mohammad A.S. Masoum \\ Electrical and Computer Engineering Department, Curtin University, Western Australia
}

\begin{abstract}
SUMMARY
Data obtained using a distributed parameter model to simulate a power transformer are presented. These data could be used in the formulation of standard codes for interpretation of the frequency response analysis signatures of power transformers.
\end{abstract}

Key Words: Power transformer, FRA, condition monitoring, winding deformation.

\section{INTRODUCTION}

THE majority of transformers currently in service worldwide were installed prior to 1980, and consequently most of them are approaching or have already exceeded their design lifetimes $[1,2]$. This poses a significant risk for utilities and other power network stakeholders, since the impact of inservice transformer failure can be catastrophic. One of the most serious problems with an in-service transformer is movement of its windings due to electromagnetic forces generated during short circuit faults. Reduction of clamping pressure due to insulation aging can also cause winding movement, and may result in an explosion [3-6]. There are many causes of mechanical faults, e.g., earthquake, explosion of combustible gas in the transformer oil, short circuit currents, and careless transportation $[7,8]$. While a transformer with minor winding deformation may continue to work satisfactorily, its capability to withstand further mechanical or electrical faults will gradually decrease [9]. Therefore it is essential to detect any minor winding deformation as soon as possible, and to take appropriate remedial action. Winding deformation has various forms, e.g., spiral tightening, conductor tilting, radial/hoop buckling, shorted or open turns, loosened clamping structures, axial displacement, core movement, and collapse of the winding end supports. It is difficult to differentiate between these internal faults using conventional testing methods [10].

In this article data obtained using a high frequency distributed parameter model to simulate a power transformer are presented. Mechanical faults such as axial displacement, radial buckling, disk space variation, loss of clamping, bushing and leakage faults were simulated by modifying the relevant electrical parameters in the transformer model, or by reconfiguring the impacted disks in a $3 \mathrm{D}$ transformer finite element model. It is suggested that the resulting data could be used in the formulation of standard codes for interpretation of the frequency response analysis signatures of power transformers.

\section{FREQUENCY RESPONSE ANALYSIS}

Frequency response analysis (FRA) is a powerful diagnostic technique widely used to identify internal faults within power transformers [11]. Transformer components such as windings, core and insulation can be represented by equivalent circuits comprising resistors, capacitors, and self / mutual inductances, whose values will be altered by a mechanical fault within the transformer. Thus the frequency response of the relevant equivalent circuit winding will change. Changes in ttransformer geometry, or in the dielectric properties of insulating materials due to ageing or increasing water content, also affect the shape of the frequency response, especially the resonant frequencies and their damping [8].

FRA is an offline technique in which a low voltage ac signal is injected at one terminal of a winding, and the response is measured at the other terminal of the same winding with reference to the grounded tank. The FRA analyzer measures the transfer function, impedance or admittance of the winding, typically over the frequency range $10 \mathrm{~Hz}-2 \mathrm{MHz}$, and one or all of these three properties can be used for fault diagnosis. Although the FRA equipment can be connected to the transformer in different ways [12-14], end-to-end connection shown in Fig. 1 is capable of detecting the main types of mechanical faults [14].

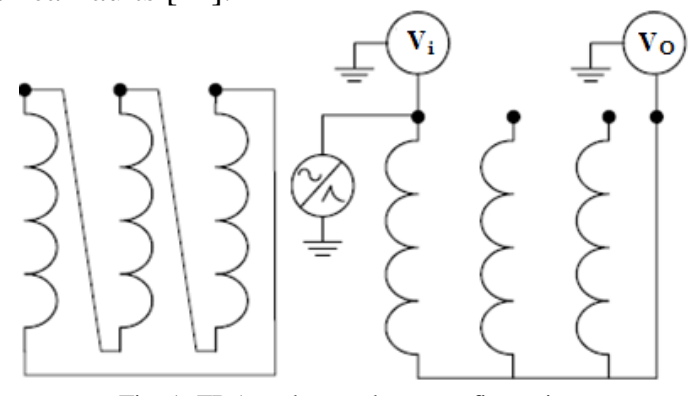

Fig. 1. FRA end-to-end test configuration

The FRA signature is considered as a fingerprint of the transformer, which can be compared with a previous signature in order to detect any mechanical deformation which may have developed between the recording of the two signatures. FRA diagnosis has also been utilized recently to identify winding deformations in rotating machines [13]. While the measurement procedure using commercial test equipment is quite simple, skilled and experienced personnel are required in order to interpret the FRA signatures and identify correctly the type and location of a fault. Although much research has been done on this topic, a reliable FRA signature interpretation code has not yet been published.

The authors of [14] sub-divide the FRA frequency range as follows:

(a) the low frequency range $(<20 \mathrm{kHz})$, within which inductive components dominate the transformer winding response 
(b) the medium frequency range (20-400 kHz), within which the combination of inductive and capacitive components results in multiple resonances

(c) the high frequency range $(>400 \mathrm{kHz})$, within which capacitive components dominate the FRA signature [15]. These ranges and the associated fault types are summarized in Table I [16, 17].

TABLE I

FRA BANDS AND THEIR SENISTIVITY TO FAULTS [16]

\begin{tabular}{|c|c|}
\hline Frequency Band & Fault sensitivity \\
\hline$<20 \mathrm{kHz}$ & $\begin{array}{c}\text { Core deformation, open circuits, shorted turns } \\
\text { and residual magnetism, bulk winding } \\
\text { movement, clamping structure loosening }\end{array}$ \\
\hline $20-400 \mathrm{kHz}$ & Deformation within the main or tap windings \\
\hline$>400 \mathrm{kHz}$ & $\begin{array}{c}\text { Movement of the main and tap windings, } \\
\text { ground impedances variations }\end{array}$ \\
\hline
\end{tabular}

\section{TRANSFormer Model AND Sensitivity ANAlysis}

Simplorer software was used to simulate the transformer model shown in Fig. 2 [17-19].

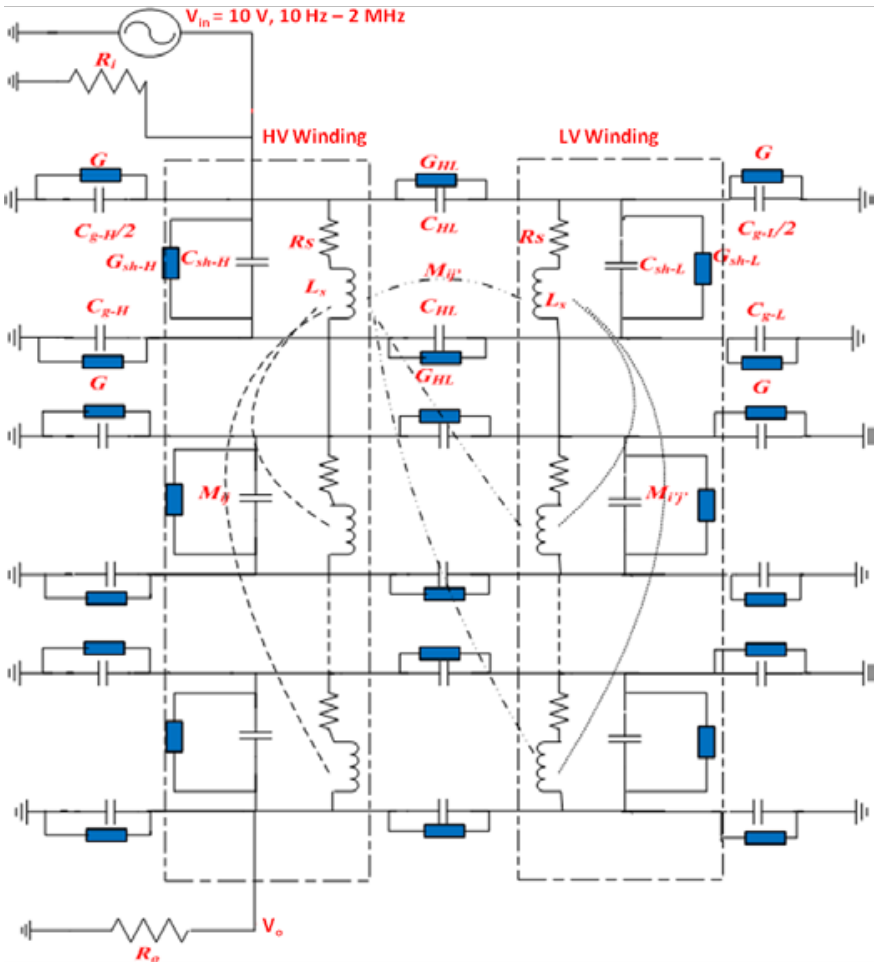

Fig. 2. 10-disk model of a transformer [17].

The high voltage (HV) and low voltage (LV) windings are each assumed to consist of 10 disks. Each disk comprises a series resistance $\left(R_{s}\right)$ and inductance $\left(L_{s}\right)$, shunted by a capacitor $\left(C_{s h}\right)$ and a conductance $\left(G_{s h}\right)$. The capacitance $\left(C_{H L}\right)$ between the $\mathrm{HV}$ and $\mathrm{LV}$ windings is shunted by a dielectric conductance $\left(G_{H L}\right)$, and mutual inductances $\left(M_{i j}\right)$ between coils $i$ and $j$ are included. The dielectric insulation (oil) between the LV winding and the core, and between the $\mathrm{HV}$ winding and the tank, is simulated by a capacitance $\left(C_{g}\right)$ and dielectric conductance $(G)$. The fault-free component values of the model given in [9] and [13] are listed in the Appendix.

In Table II the transformer model parameters, and the mechanical faults which influence them, are listed. Various mechanical faults can be simulated by changing relevant parameters in the transformer model. This can aid in establishing a standard code for FRA signature interpretation.

Table II

MODEL PARAMETERS AND THE MECHANICAL FAULTS WHICH INFLUENCE THEM [9], [11], [17], [20]-[23]

\begin{tabular}{|l|l|}
\hline Model Parameter & Type of Fault \\
\hline Inductance $\mathrm{L}_{\mathrm{s}}$ & $\begin{array}{l}\text { Disk deformation, local breakdown, core } \\
\text { deformation and winding short circuits. }\end{array}$ \\
\hline $\begin{array}{l}\text { Shunt Capacitance } \\
\mathrm{C}_{\mathrm{sh}}\end{array}$ & $\begin{array}{l}\text { Disk movements, buckling due to large } \\
\text { mechanical forces, moisture ingress and loss of } \\
\text { clamping pressure. }\end{array}$ \\
\hline Series Capacitance & $\begin{array}{l}\text { Ageing of insulation, moisture ingress and disk } \\
\text { movement. }\end{array}$ \\
\hline $\mathrm{C}_{\mathrm{HL}}$ & $\begin{array}{l}\text { Shorted or broken disk, failure of caulking } \\
\text { contacts and tap changer contact wear. }\end{array}$ \\
\hline
\end{tabular}

The sensitivity of the FRA signature to variation of the model parameters was investigated. As shown in Fig. 2, a sinusoidal excitation voltage $\left(V_{i n}\right)$ of $10 \mathrm{~V}$ and variable frequency $(10 \mathrm{~Hz}$ to $2 \mathrm{MHz}$ ) is connected to one winding terminal, and the response at the other terminal of the winding $\left(V_{o}\right)$ is recorded. The input/output coaxial leads used in practical measurements are represented by $50 \Omega$ resistors $\left(R_{i}\right.$ and $R_{o}$ in Fig. 2). The transfer function $\mathrm{TF}_{\mathrm{dB}}=20 \log _{10}\left|V_{0}\right|$ $V_{i n} \mid$ is plotted against frequency. Fig. 3 shows the effect of $\pm 10 \%$ changes in the capacitances $C_{g}$ and $C_{s h}$ of the HV winding on the FRA signature, compared to the base line (fingerprint) signature. Increasing $C_{s h}$ decreases the resonance and anti-resonance frequencies, i.e., the local minimum and local maximum frequencies respectively, with small changes in magnitude. Decreasing $C_{s h}$ increases the resonance and antiresonance frequencies. The same trends are observed for $C_{g}$ variation. It will be seen that the impact of varying $C_{g}$ and $C_{s h}$ is more pronounced at frequencies above $400 \mathrm{kHz}$.
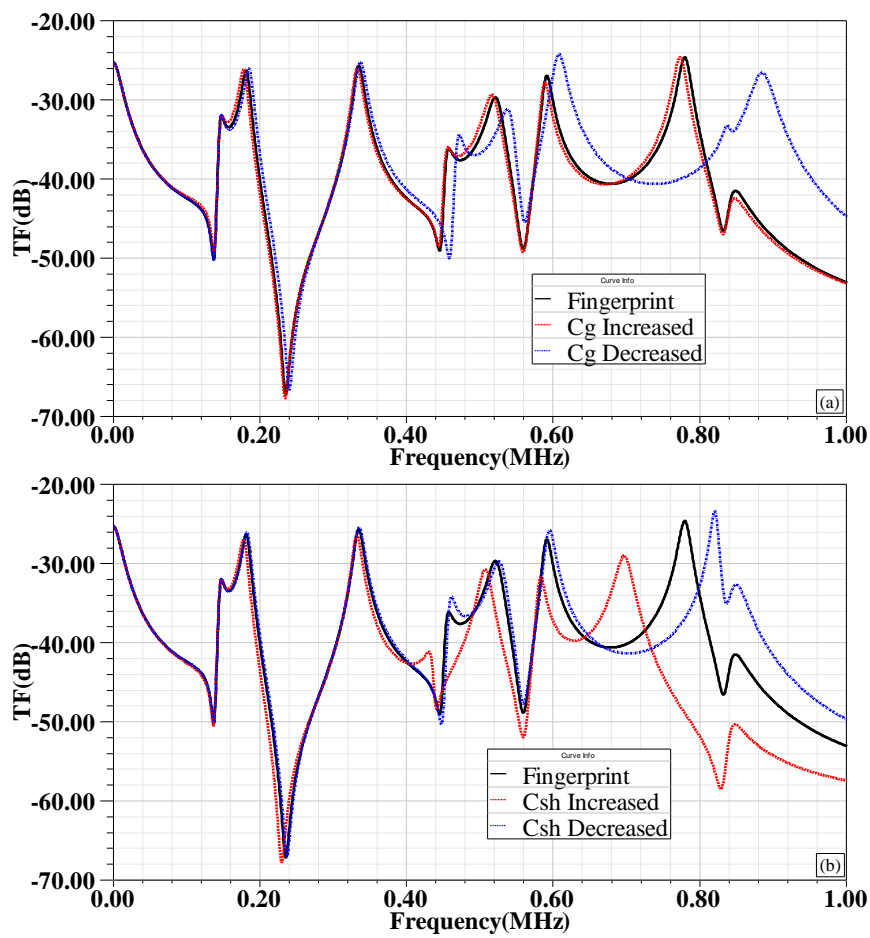

Fig. 3. Effect of $\pm 10 \%$ changes in the HV capacitance on the FRA signature, relative to the baseline (a) $C_{g}$, (b) $C_{s h}$ 
Fig. 4 shows the effect of changing the self $\left(L_{s}\right)$ and mutual $\left(M_{i j}\right)$ inductances by $\pm 10 \%$. Unlike the effect of changes in $C_{g}$ and $C_{s h}$, which appears at frequencies above 400 $\mathrm{kHz}$, the effect of changes in $L_{s}$ and $M_{i j}$ appears below $20 \mathrm{kHz}$ and is more pronounced close to $1 \mathrm{MHz}$. This is attributed to the fact that the amount of magnetic flux penetrating the transformer core at low frequencies is significant, so that the core characteristics affect the FRA signature at low frequency. At high frequencies the magnetic flux tends to encase the core and the transformer capacitive components dominate the response.
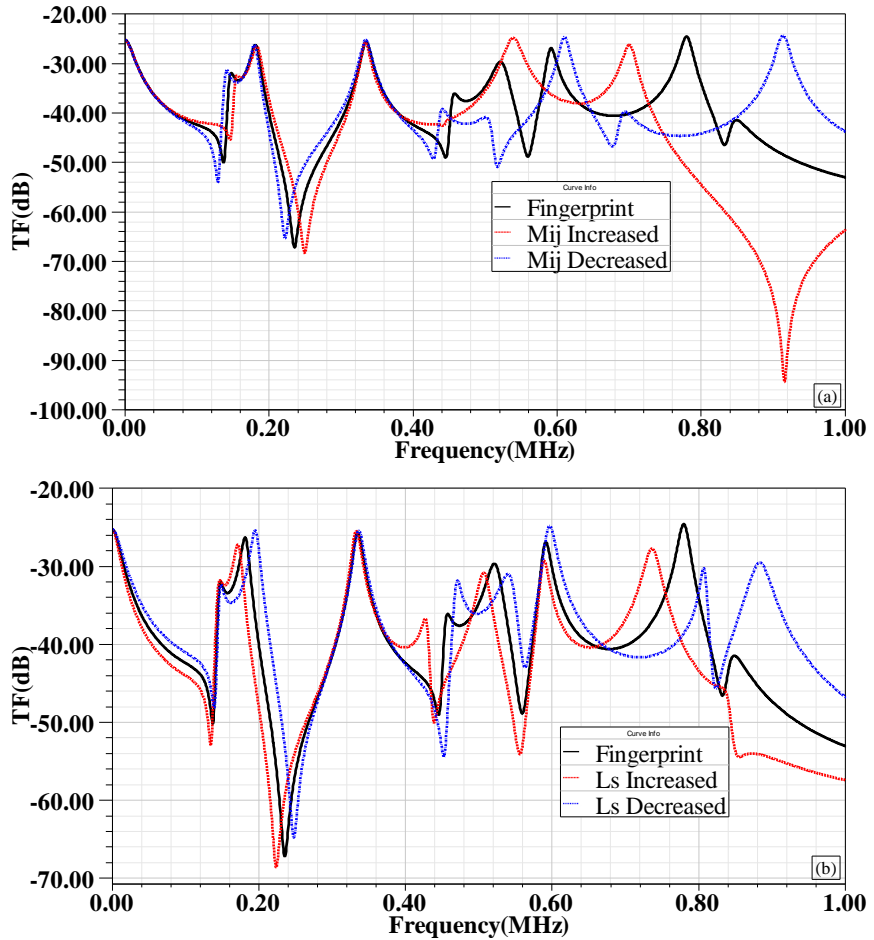

Fig. 4. Effect of $\pm 10 \%$ changes in the HV self/mutual inductances on the FRA signature, relative to the baseline (a) mutual inductance $M_{i j}$ (b) self inductance $L_{S}$

As shown in Fig. 4, increasing $L_{s}$ decreases the resonance and anti-resonance frequencies, with small changes in magnitude. On the other hand, decreasing $L_{s}$ increases the resonance and anti-resonance frequencies, again with small changes in magnitude. Opposite trends are observed when the mutual inductances $M_{i j}$ are changed, i.e., increasing $M_{i j}$ increases the resonance and anti-resonance frequencies, and decreasing $M_{i j}$ decreases them, over the entire frequency range.

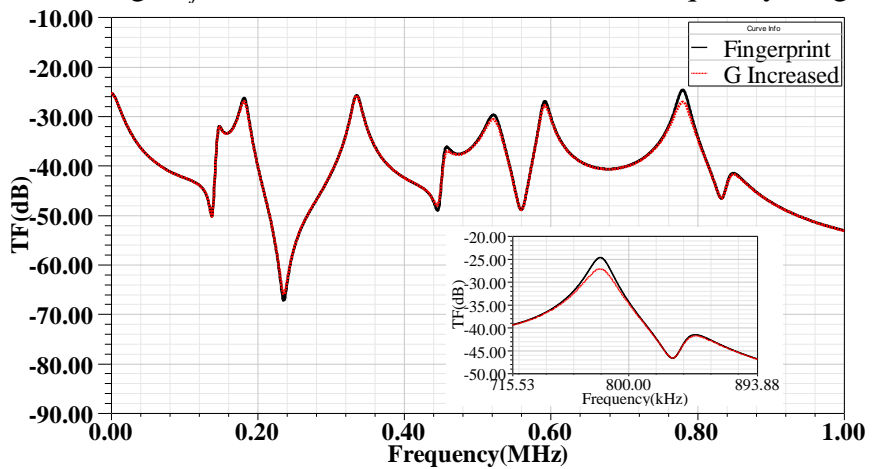

Fig. 5. Effect of increased dielectric conductance $G$ on the FRA signature
Fig. 5 shows the effect increasing the HV conductance $(G)$ by $10 \%$ on the FRA signature (A decrease in conductance, i.e., an increase in dielectric resistance, is considered unlikely for transformer insulation). As shown in Fig. 5, increasing the dielectric conductance $(G)$ has no effect on the resonance and anti-resonance frequencies. It does however slightly change the magnitudes of the peaks at high frequencies. This result is attributed to the very high dielectric resistance used in the simulation (7 M $\Omega$ ), typical for transformer oil.

The effects of $\pm 10 \%$ variations in various electrical parameters on the FRA resonance frequencies and magnitudes are summarised in Table III.

TABLE III

EFFECTS OF $\pm 10 \%$ VARIATIONS IN VARIOUS ELECTRICAL PARAMETERS ON FRA REONANCE FREQUENCIES AND MAGNITUDES (RELATIVE TO FINGERPRINTS)

\begin{tabular}{|c|c|c|c|c|}
\hline \multirow{2}{*}{\multicolumn{2}{|c|}{$\begin{array}{l}\text { Parameter } \\
\text { Variations }\end{array}$}} & \multicolumn{3}{|c|}{ Frequency Range } \\
\hline & & $\begin{array}{c}\text { Low } \\
(<20 \mathrm{kHz})\end{array}$ & $\begin{array}{c}\text { Medium } \\
(20-400 \mathrm{kHz})\end{array}$ & $\begin{array}{c}\text { High } \\
(>400 \mathrm{kHz})\end{array}$ \\
\hline \multirow[b]{2}{*}{$L_{s}$} & $\begin{array}{c}10 \% \\
\text { Increase }\end{array}$ & $\begin{array}{c}\text { Magnitude and } \\
\text { resonance frequencies } \\
\text { decreased }\end{array}$ & $\begin{array}{l}\text { Magnitude and } \\
\text { resonance } \\
\text { frequencies } \\
\text { decreased }\end{array}$ & $\begin{array}{l}\text { Magnitude } \\
\text { and } \\
\text { resonance } \\
\text { frequencies } \\
\text { decreased }\end{array}$ \\
\hline & $\begin{array}{c}10 \% \\
\text { Decrease }\end{array}$ & $\begin{array}{l}\text { Magnitude and } \\
\text { resonance } \\
\text { frequencies } \\
\text { increased }\end{array}$ & $\begin{array}{l}\text { Magnitude and } \\
\text { resonance } \\
\text { frequencies } \\
\text { increased }\end{array}$ & $\begin{array}{l}\text { Magnitude } \\
\text { and } \\
\text { resonance } \\
\text { frequencies } \\
\text { increased }\end{array}$ \\
\hline \multirow{2}{*}{$C_{s h}$} & $\begin{array}{c}10 \% \\
\text { Increase }\end{array}$ & No impact & No impact & $\begin{array}{c}\text { Resonance } \\
\text { frequencies, } \\
\text { magnitude } \\
\text { decreased }\end{array}$ \\
\hline & $\begin{array}{c}10 \% \\
\text { Decrease }\end{array}$ & No impact & No impact & $\begin{array}{c}\text { Resonance } \\
\text { frequencies, } \\
\text { magnitude } \\
\text { increased }\end{array}$ \\
\hline \multirow[b]{2}{*}{$C_{g}$} & $\begin{array}{c}10 \% \\
\text { Increase }\end{array}$ & No impact & No impact & $\begin{array}{c}\text { Resonance } \\
\text { frequencies } \\
\text { slightly } \\
\text { decreased } \\
\end{array}$ \\
\hline & $\begin{array}{c}10 \% \\
\text { Decrease }\end{array}$ & No impact & No impact & $\begin{array}{c}\text { Resonance } \\
\text { frequencies, } \\
\text { magnitude } \\
\text { increased }\end{array}$ \\
\hline \multirow[b]{2}{*}{$M_{i j}$} & $\begin{array}{c}10 \% \\
\text { Increase }\end{array}$ & $\begin{array}{l}\text { Resonance } \\
\text { frequencies } \\
\text { increased } \\
\end{array}$ & $\begin{array}{c}\text { Resonance } \\
\text { frequencies } \\
\text { increased } \\
\end{array}$ & $\begin{array}{l}\text { Resonance } \\
\text { frequencies } \\
\text { increased } \\
\end{array}$ \\
\hline & $\begin{array}{c}10 \% \\
\text { Decrease }\end{array}$ & $\begin{array}{c}\text { Resonance } \\
\text { frequencies } \\
\text { decreased }\end{array}$ & $\begin{array}{c}\text { Resonance } \\
\text { frequencies } \\
\text { decreased }\end{array}$ & $\begin{array}{l}\text { Resonance } \\
\text { frequencies } \\
\text { decreased }\end{array}$ \\
\hline $\boldsymbol{G}$ & $\begin{array}{c}10 \% \\
\text { Increase }\end{array}$ & No impact & No impact & $\begin{array}{l}\text { Magnitude } \\
\text { decreased }\end{array}$ \\
\hline
\end{tabular}

\section{FAULT ANALYSIS}

In order to simulate physical faults within the transformer, Simplorer and Maxwell software were used to simulate a 3D finite element model of the single phase, shell-type transformer shown in Fig. 6.

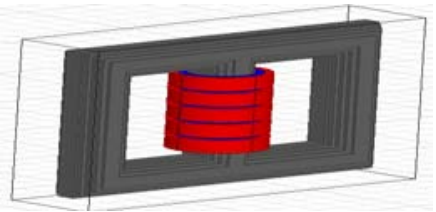

Fig. 6. 3D Transformer model 
Various mechanical faults within the transformer model were simulated by changing the transformer coil configuration. The corresponding changes in the electrical parameters of the transformer model (Fig. 2) were calculated using the software. The resulting signatures were compared with the fingerprint signature.

\section{A. Loss of Clamping Pressure}

Loss of clamping pressure is a common problem, particularly in aged transformers. It is caused by mechanical hysteresis in pressboard and paper insulation [24], and leads to an increase in insulation conductivity because of the reduced insulation thickness between winding layers. It can be simulated by increasing the value of the shunt conductance $G_{s h}$ [21]. Figs. 7 and 8 show the effect of a $20 \%$ increase in $G_{s h}$ on the FRA signatures of the $\mathrm{HV}$ and $\mathrm{LV}$ windings respectively; the resonance and anti-resonance frequencies are not shifted, but the magnitudes of the resonance peaks are decreased over the entire frequency range. The large negative spike in the HV winding signature around $200 \mathrm{kHz}$ is thought to be an artefact of the software.

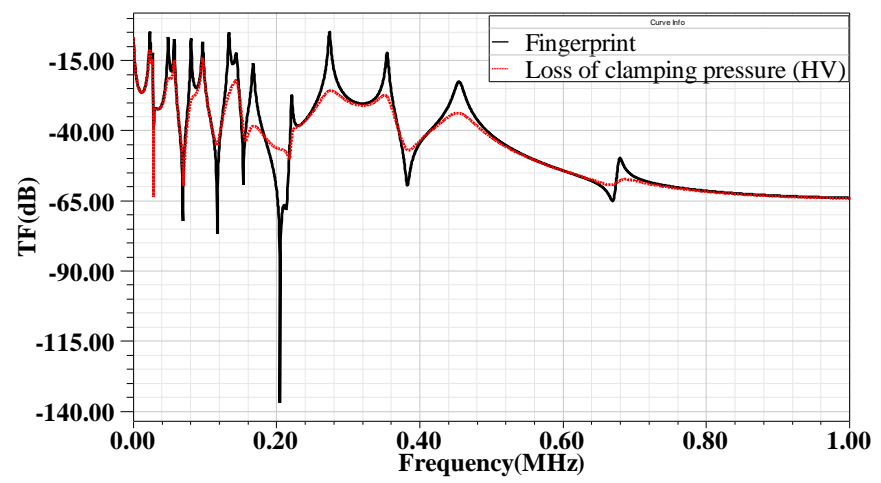

Fig. 7. Effect of simulated loss of clamping pressure on the FRA signature of the $\mathrm{HV}$ winding

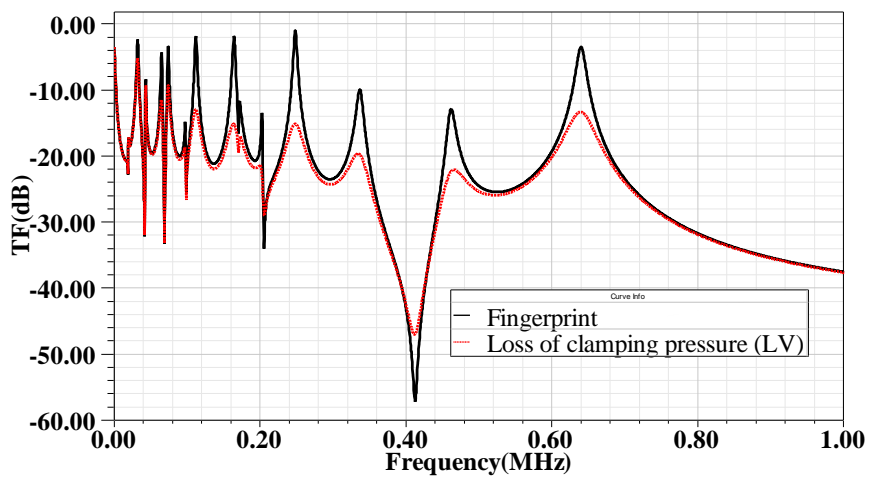

Fig. 8. Effect of simulated loss of clamping pressure on the FRA signature of the $\mathrm{LV}$ winding

\section{B. Inter-Disk Fault}

The inter-disk fault is one of the most common mechanical faults within power transformers, and approximately $80 \%$ of mechanical failures are attributable to it [12]. It is due to changes in the axial disk space (Fig.9) caused by excess mechanical stress and short circuit faults, and can be simulated by increasing the series capacitance $\left(C_{s h}\right)$ and the mutual inductance $\left(M_{i j}\right)$ between the two relevant disks [25, 26]. Fig. 10 shows the effect of a $10 \%$ increase in $\mathrm{C}_{\mathrm{sh}}$ and $\mathrm{M}_{\mathrm{ij}}$ on the $\mathrm{HV}$ FRA signature when the fault occurs at the top, middle and bottom of the $\mathrm{HV}$ winding. A $10 \%$ increase in $C_{\text {sh }}$ and in $M_{i j}$ corresponds to a $10 \%$ increase in $\Delta h$, the space between the affected disks (Fig. 9). Fig. 10 shows that this fault does not have a significant effect on the FRA signature at frequencies below $300 \mathrm{kHz}$. The resonance and anti-resonance frequencies above $300 \mathrm{kHz}$ are decreased, and the peak magnitudes are changed. The frequency decreases are larger when the fault occurs within the top or bottom disks of the winding, rather than within the middle disks.

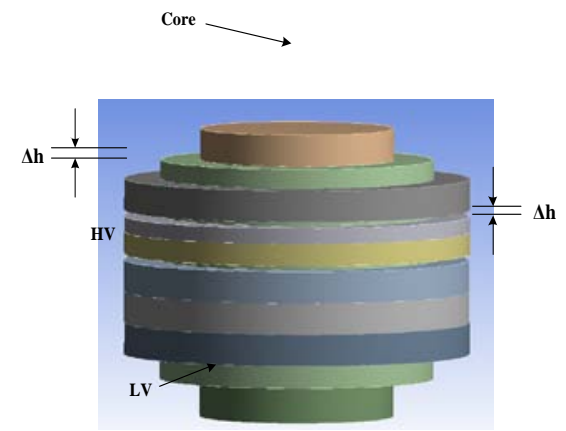

Fig. 9. Interdisk fault $(\Delta \mathrm{h})$ configuration
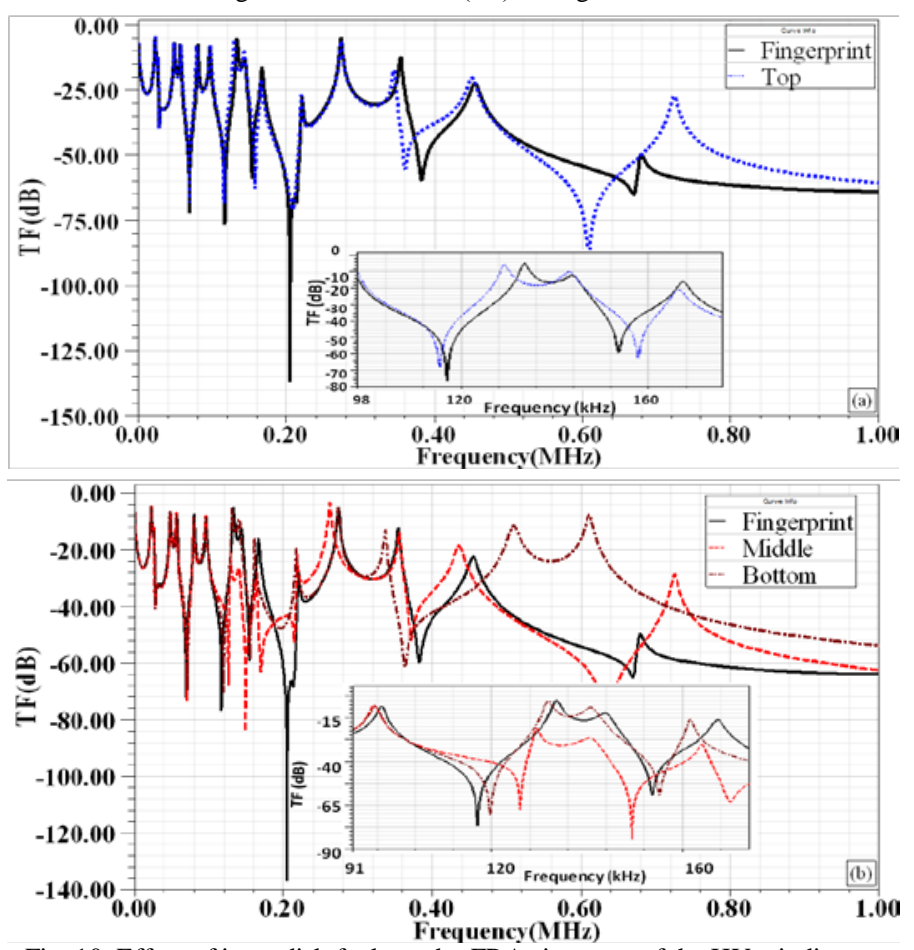

Fig. 10. Effect of inter-disk fault on the FRA signature of the HV winding.

\section{HV Winding Bushing Fault}

This type of fault can be simulated by connecting the bushing T-circuit model shown in Fig. 11 between the voltage source $\mathrm{V}_{\text {in }}$ and the transformer model shown in Fig. 2 [5].

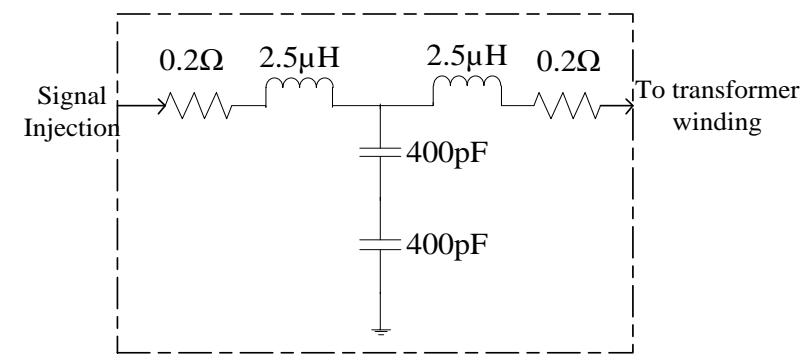

Fig. 11. Transformer bushing model [5] 


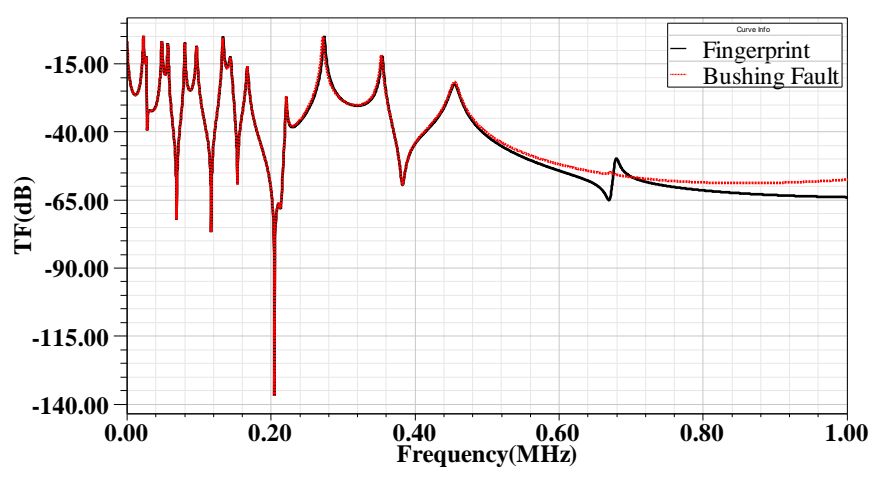

Fig. 12. Impact of high voltage bushing fault on the FRA signature of the HV winding

The effect of a $10 \%$ reduction in bushing capacitance (800 pF) shown in Fig. 11 on the FRA signature is shown in Fig. 12. A reduction in bushing capacitance corresponds to a reduction in the breakdown voltage of the bushing insulation. As shown in Fig. 12, there is no significant change in the signature below $600 \mathrm{kHz}$, but the resonance and antiresonance peaks around $700 \mathrm{kHz}$ in the fingerprint disappear.

\section{Axial Displacement Fault}

This fault occurs due to imbalanced magnetic forces generated in a winding as a result of a short-circuit fault [21]. These forces cause axial movement of the winding as shown in Fig. 13.

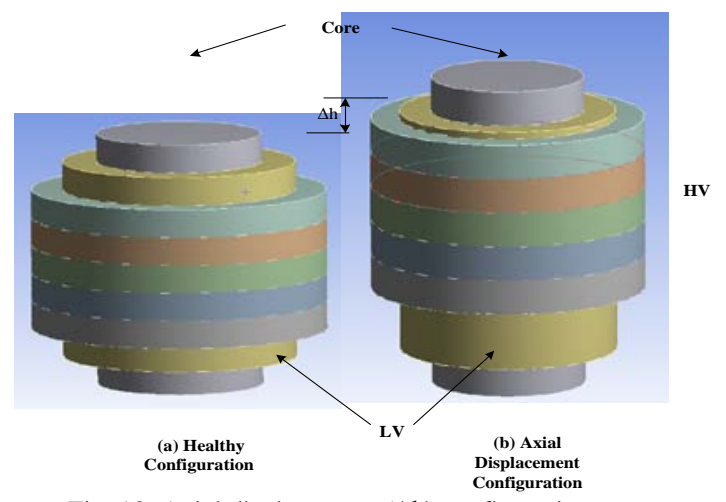

Fig. 13. Axial displacement $(\Delta \mathrm{h})$ configuration

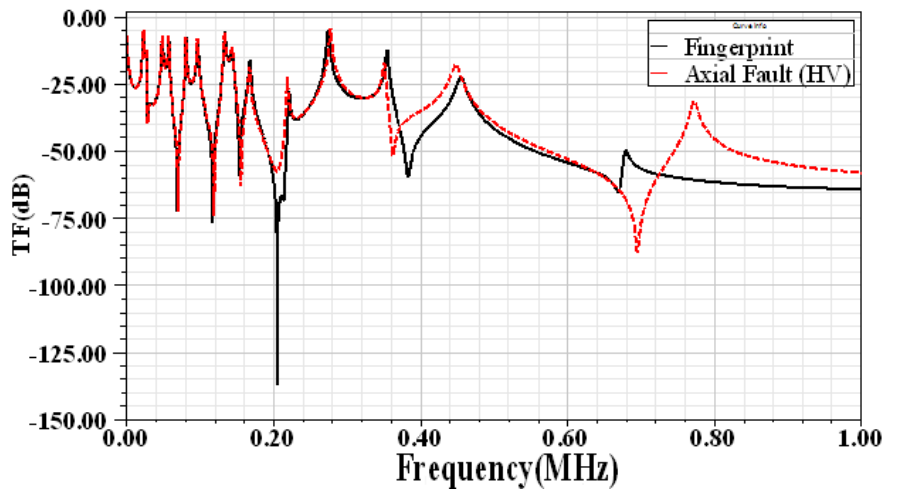

Fig. 14. Impact of HV axial displacement on the FRA signature

The fault can be simulated by changing the values of the series capacitance $\left(C_{\text {sh }}\right)$ and mutual inductance $\left(M_{i j}\right)$ between the $\mathrm{HV}$ and $\mathrm{LV}$ windings [27]. A $10 \%$ increase in $C_{H L}$ and in $M_{i j}$ corresponds to approximately $10 \%$ movement $\Delta \mathrm{h}$ which is the ratio of the HV axial displacement and the overall length of the winding (Fig. 13).

Fig. 14 shows that such a fault has little effect on the FRA signature below $200 \mathrm{kHz}$. In the range $200-400 \mathrm{kHz}$ the resonance frequencies and magnitudes decrease. The resonance around $700 \mathrm{kHz}$ in the fingerprint is shifted towards higher frequency and its magnitude increases. These trends are independent of the direction of the axial movement.

\section{E. Dielectric Leakage Current Fault}

Ground shield damage, oil and paper aging, high moisture content in the winding and abrasion of solid insulation are the main causes of leakage current to earth through transformer insulation [28]. This type of fault can be simulated by increasing the conductance between the HV winding and the ground ( $G$ in Fig.2) [29]. Fig. 15 shows that this fault produces small changes in peak magnitude below $200 \mathrm{kHz}$.

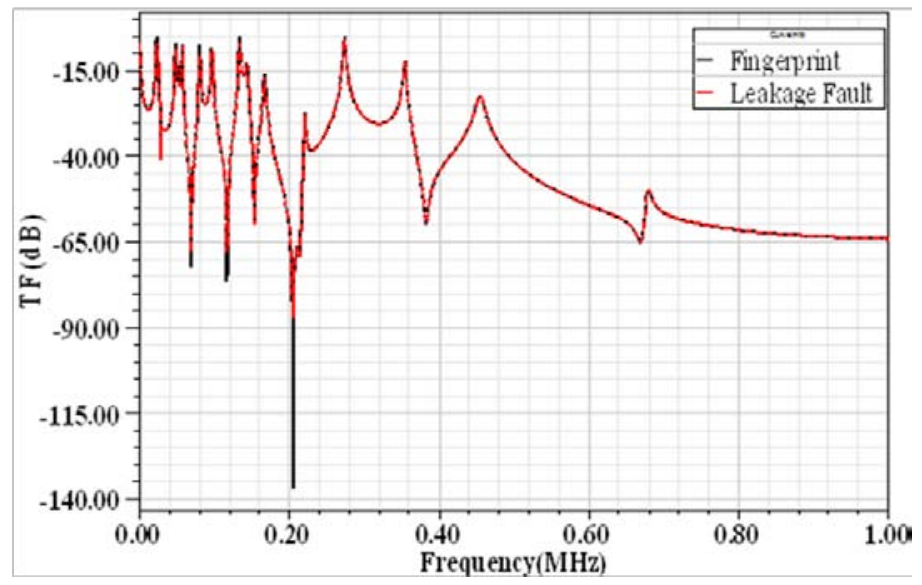

Fig. 15. Effect of leakage fault on the FRA signature

\section{F. Short Circuit Fault}

This fault is due to erosion of the winding and conductor insulation, due to vibrations generated by electromechanical forces. The erosion may lead to excessive current in the winding [27]. The fault can be simulated by short circuiting the series resistance $R_{s}$ and the series inductance $L_{s}$ of the HV winding (Fig.2) [30]. Fig. 16 shows that it fault has little effect on the signature at frequencies below $200 \mathrm{kHz}$. At higher frequencies the magnitude is slightly increased and the resonance frequencies are slightly decreased. The same fault has a greater effect when it occurs at the top or bottom of the winding rather than in the middle.

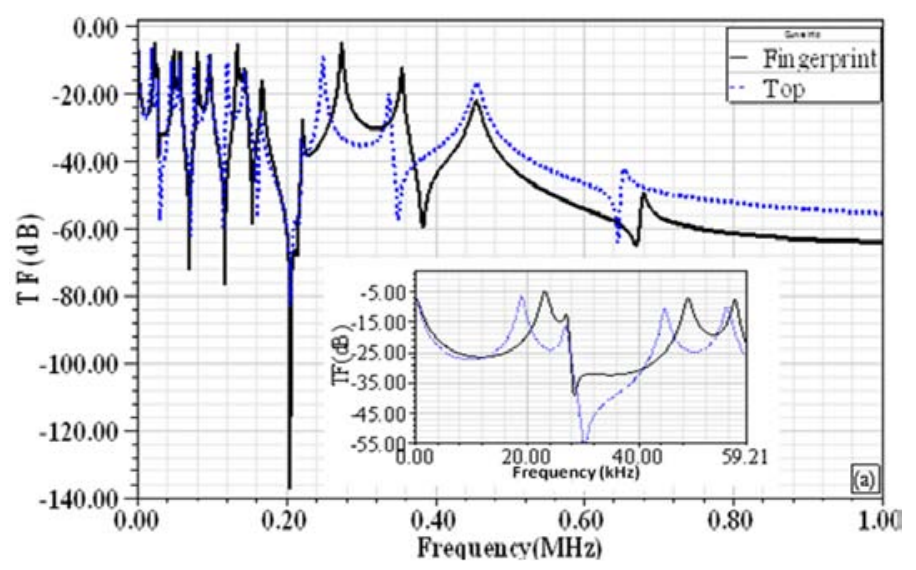




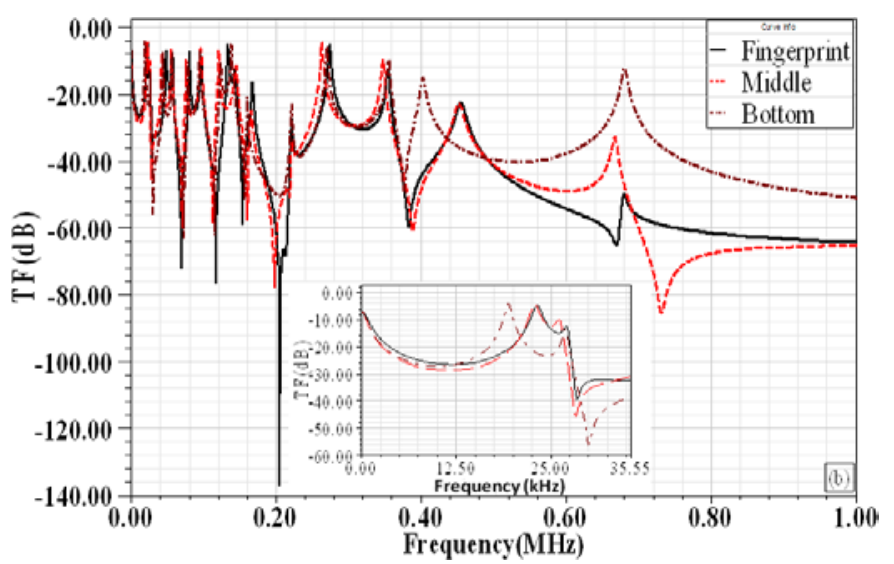

Fig. 16. Impact of $\mathrm{HV}$ winding short circuit fault on the FRA signature when it occurs (a) at the top of the winding, (b) at the middle and bottom of the winding

\section{G. Radial Displacement Fault}

Windings may be subjected to radial forces arising from the interaction of the winding current with the magnetic flux. Fig.17 shows a radial dislocation between the LV and HV windings. Large radial forces may lead to winding buckling [31]. This fault can be simulated by decreasing the capacitance to ground $\left(C_{g}\right)$, the capacitance between the $\mathrm{HV}$ and $\mathrm{LV}$ windings $\left(C_{\mathrm{HL}}\right)$, and the mutual inductance $\left(M_{i j}\right)$ of the impacted disks [32]. A simultaneous decrease of $10 \%$ in each of these three parameters corresponds to a $10 \%$ radial displacement $\Delta \mathrm{w}$ of the impacted disks as shown in Fig. 17. $\Delta \mathrm{w}$ is calculated as the ratio of the radial displacement of the impacted disks to the diameter of the disk. The FRA responses of the $\mathrm{HV}$ and $\mathrm{LV}$ windings are shown in Fig. 18 (a) and (b) respectively.

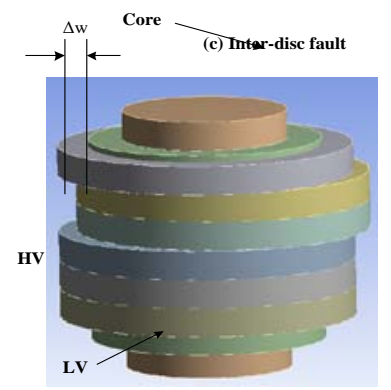

Fig. 17. Radial fault $(\Delta w)$ configuration

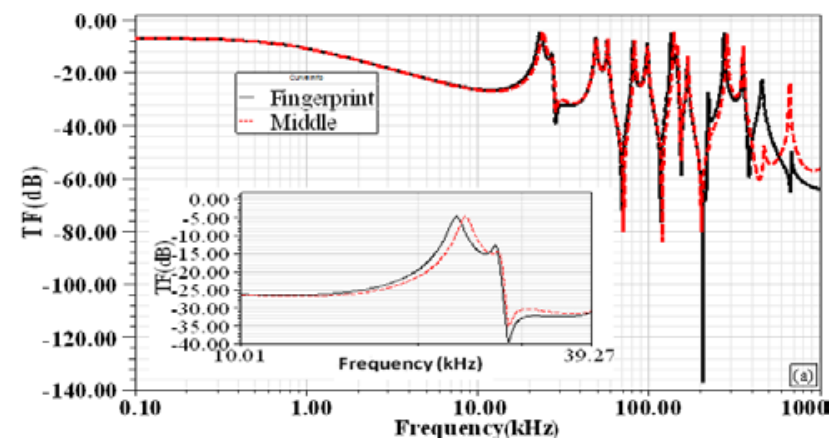

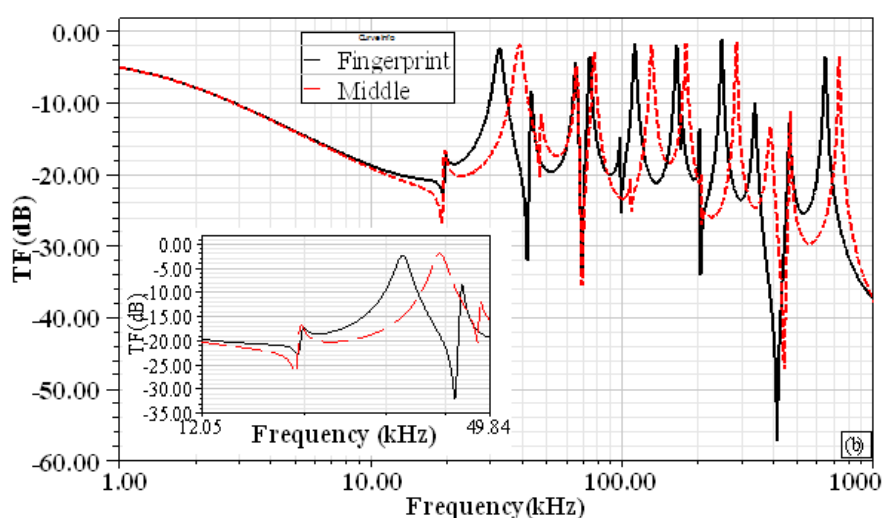

Fig. 18. Impact of radial fault on the FRA signature (a)HV (b) LV winding

Fig. 18 (a) shows that the resonance frequencies of the HV winding are increased slightly at frequencies above $400 \mathrm{kHz}$. In the $\mathrm{LV}$ winding an increase occurs at frequencies above 20 $\mathrm{kHz}$.

Table IV is a listing of the various fault types and their effects on the FRA signature. It could be used in the formulation of standard codes for power transformer FRA signature interpretation.

TABLE IV

IMPACT OF VARIOUS FAULTS ON TRANSFORMER FRA SIGNATURE

\begin{tabular}{|c|c|c|c|}
\hline \multirow{2}{*}{ Fault Type } & \multicolumn{3}{|c|}{ Frequency Range } \\
\hline & $<20 \mathrm{kHz}$ & $20-400 \mathrm{kHz}$ & $>400 \mathrm{kHz}$ \\
\hline $\begin{array}{c}\text { Axial } \\
\text { Displacement }\end{array}$ & No impact & $\begin{array}{c}\text { Resonance } \\
\text { frequencies and } \\
\text { magnitude } \\
\text { decreased }\end{array}$ & $\begin{array}{c}\text { Resonance } \\
\text { frequencies and } \\
\text { magnitude } \\
\text { increased }\end{array}$ \\
\hline $\begin{array}{c}\text { Radial } \\
\text { Displacement }\end{array}$ & $\begin{array}{l}\text { Resonance } \\
\text { frequencies } \\
\text { increased }\end{array}$ & $\begin{array}{l}\text { Resonance } \\
\text { frequencies } \\
\text { increased }\end{array}$ & $\begin{array}{l}\text { Resonance } \\
\text { frequencies } \\
\text { increased }\end{array}$ \\
\hline $\begin{array}{c}\text { High Voltage } \\
\text { Bushing }\end{array}$ & No impact & No impact & $\begin{array}{c}\text { Magnitude } \\
\text { decreased, one } \\
\text { resonance } \\
\text { frequency } \\
\text { disappears }\end{array}$ \\
\hline $\begin{array}{c}\text { Dielectric } \\
\text { Leakage } \\
\text { current }\end{array}$ & $\begin{array}{c}\text { Magnitude } \\
\text { decreased }\end{array}$ & $\begin{array}{l}\text { Magnitude } \\
\text { decreased }\end{array}$ & No impact \\
\hline Inter Disk & $\begin{array}{l}\text { No significant } \\
\text { impact }\end{array}$ & $\begin{array}{c}\text { Resonance } \\
\text { frequencies and } \\
\text { magnitudes } \\
\text { increased }\end{array}$ & $\begin{array}{c}\text { Resonance } \\
\text { frequencies and } \\
\text { magnitudes } \\
\text { increased }\end{array}$ \\
\hline Short Circuit & $\begin{array}{l}\text { No significant } \\
\text { impact }\end{array}$ & $\begin{array}{c}\text { Resonance } \\
\text { frequencies } \\
\text { decreased and } \\
\text { magnitudes } \\
\text { increased } \\
\end{array}$ & $\begin{array}{c}\text { Resonance } \\
\text { frequencies } \\
\text { decreased and } \\
\text { magnitudes } \\
\text { increased } \\
\end{array}$ \\
\hline $\begin{array}{c}\text { Loss of } \\
\text { Clamping } \\
\text { Pressure }\end{array}$ & $\begin{array}{l}\text { Magnitude } \\
\text { decreased }\end{array}$ & $\begin{array}{l}\text { Magnitude } \\
\text { decreased }\end{array}$ & $\begin{array}{l}\text { Magnitude } \\
\text { decreased }\end{array}$ \\
\hline
\end{tabular}

\section{CONCLUSION}

This paper presents a comprehensive analysis of the effects of various faults on the FRA signatures of a transformer simulated by a high frequency model. The faults were simulated through changes in the values of some of the electrical components in the model. It was found that radial displacement of a winding alters the FRA signature over the entire frequency range $(10 \mathrm{~Hz}-1 \mathrm{MHz})$, whereas changes due 
to axial displacement occur only at frequencies above 200 $\mathrm{kHz}$. A table listing various transformer faults and the associated changes in the FRA signature was compiled, and could be used in the formulation of standard codes for power transformer FRA signature interpretation.

\section{APPENDIX}

TRANSFORMER MODEL COMPONENT VALUES [9, 13]

\begin{tabular}{|c|c|c|c|c|c|c|}
\cline { 2 - 7 } \multicolumn{1}{c|}{} & $R_{s}$ & $L_{s}$ & $C_{s h}$ & $C_{g}$ & $C_{h l}$ & $1 / G$ \\
\hline $\mathrm{HV}$ & $1.2 \Omega$ & $180 \mu \mathrm{H}$ & $0.013 \mathrm{nF}$ & $3 \mathrm{nF}$ & $5 \mathrm{nF}$ & $7 \mathrm{M} \Omega$ \\
\hline $\mathrm{LV}$ & $0.5 \Omega$ & $65 \mu \mathrm{H}$ & $0.026 \mathrm{nF}$ & $6 \mathrm{nF}$ & $5 \mathrm{Nf}$ & $7 \mathrm{M} \Omega$ \\
\hline
\end{tabular}

\section{REFERENCES}

[1] S. Islam, K. M. Coates, and G. Ledwich, "Identification of high frequency transformer equivalent circuit using Matlab from frequency domain data," in Industry Applications Conference, 1997. Thirty-Second IAS Annual Meeting, IAS '97., Conference Record of the 1997 IEEE, 1997, pp. 357-364 vol.1.

[2] E.J. Figueroa,"Managing An Aging Fleet of Transformers," Canada, 2009. [3]L. M. Geldenhuis, "Power transformer life management," in Electricity Distribution, 2005. CIRED 2005. 18th International Conference and Exhibition on, 2005, pp. 1-4.

[4]S. M. Islam and G. Ledwich, "Locating transformer faults through sensitivity analysis of high frequency modeling using transfer function approach," in Electrical Insulation, 1996., Conference Record of the 1996 IEEE International Symposium on, 1996, pp. 38-41 vol.1.

[5]M. Wang, A. J. Vandermaar, and K. D. Srivastava, "Improved detection of power transformer winding movement by extending the FRA high frequency range," Power Delivery, IEEE Transactions on, vol. 20, pp. 1930-1938, 2005.

[6]W. J. McNutt, W. M. Johnson, R. A. Nelson, and R. E. Ayers, "Power Transformen Short-Circuit Strength - Requirements, Design, and Demonstration," Power Apparatus and Systems, IEEE Transactions on, vol. PAS-89, pp. 1955-1969, 1970.

[7]M. Bagheri, M. S. Naderi, T. Blackburn, and T. Phung, "FRA vs. short circuit impedance measurement in detection of mechanical defects within large power transformer," in Electrical Insulation (ISEI), Conference Record of the 2012 IEEE International Symposium on, 2012, pp. 301-305.

[8]K. G. N. B. Abeywickrama, Y. V. Serdyuk, and S. M. Gubanski, "Exploring possibilities for characterization of power transformer insulation by frequency response analysis (FRA)," Power Delivery, IEEE Transactions on, vol. 21, pp. 1375-1382, 2006.

[9]E. Rahimpour, M. Jabbari, and S. Tenbohlen, "Mathematical Comparison Methods to Assess Transfer Functions of Transformers to Detect Different Types of Mechanical Faults," Power Delivery, IEEE Transactions on, vol. 25, pp. 2544-2555, 2010.

[10]B. J. Small and A. Abu-Siada, "A new method for analysing transformer condition using frequency response analysis," in Power and Energy Society General Meeting, 2011 IEEE, 2011, pp. 1-5.

[11]S. D. Mitchell and J. S. Welsh, "Modeling Power Transformers to Support the Interpretation of Frequency-Response Analysis," Power Delivery, IEEE Transactions on, vol. 26, pp. 2705-2717, 2011.

[12]E. Rahimpour, J.Christian, K. Feser, H. Mohseni, "Transfer Function Method to Diagnose Axial Displacement, Radial Deformation of Transformer Winding," Power Engineering Review, IEEE, vol.22, pp.70-70, 2002.

[13] C. A. Platero, F. Blazquez, P. Frias, and D. Ramirez,"Influence of Rotor Position in FRA Response for Detection of Insulation Failures in Salient-Pole Synchronous Machines," IEEE Transactions on Energy Conversion, vol. 26, pp. 671-676, June 2011.

[14]E. P. Dick and C. C. Erven, "Transformer Diagnostic Testing by Frequuency Response Analysis," Power Apparatus and Systems, IEEE Transactions on, vol. PAS-97, pp. 2144-2153, 1978.

[15]W. Zhongdong, L. Jie, and D. M. Sofian, "Interpretation of Transformer FRA Responses\&\#x2014; Part I: Influence of Winding Structure," Power Delivery, IEEE Transactions on, vol. 24, pp. 703-710, 2009.

[16]A. Shintemirov, W. H. Tang, and Q. H. Wu, "Transformer winding condition assessment using frequency response analysis and evidential reasoning," Electric Power Applications, IET, vol. 4, pp. 198-212, 2010.

[17]E. Rahimpour, J. Christian, K. Feser, H. Mohseni,"Transfer function method to diagnose axial displacement and radial deformation of transformer windings," Power Delivery, IEEE Transactions on, vol. 18, pp.493-505, 2003. [18]L. Satish and S. K. Sahoo, "An effort to understand what factors affect the transfer function of a two-winding transformer," Power Delivery, IEEE Transactions on, vol. 20, pp. 1430-1440, 2005.
[19]K. Ragavan and L. Satish, "Localization of Changes in a Model Winding Based on Terminal Measurements: Experimental Study," Power Delivery, IEEE Transactions on, vol. 22, pp. 1557-1565, 2007.

[20]A. Shintemirov, W. H. Tang, and Q. H. Wu, "Transformer Core Parameter Identification Using Frequency Response Analysis," Magnetics, IEEE Transactions on, vol. 46, pp. 141-149, 2010.

[21]A. Abu-siada and S. Islam, "A Novel Online Technique to Detect Power Transformer Winding Faults," Power Delivery, IEEE Transactions on, vol. 27, pp. 849-857, 2012.

[22]A. A. Reykherdt and V. Davydov, "Case studies of factors influencing frequency response analysis measurements and power transformer diagnostics," Electrical Insulation Magazine, IEEE, vol. 27, pp. 22-30, 2011.

[23]N. Abeywickrama, Y. V. Serdyuk, and S. M. Gubanski, "High-Frequency Modeling of Power Transformers for Use in Frequency Response Analysis (FRA)," Power Delivery, IEEE Transactions on, vol. 23, pp. 2042-2049, 2008. [24]G. Junfeng, G. Wensheng, T. Kexiong, and G. Shengyou, "Deformation analysis of transformer winding by structure parameter," in Properties and Applications of Dielectric Materials, 2003. Proceedings of the 7th International Conference on, 2003, pp. 487-490 vol.1.

[25]D. M. Sofian, W. Zhongdong, and L. Jie, "Interpretation of Transformer FRA Responses\&\#x2014; Part II: Influence of Transformer Structure," Power Delivery, IEEE Transactions on, vol. 25, pp. 2582-2589, 2010.

[26]E. Rahimpour, S. Tenbohlen, "Experimental and theoretical investigation of disc space variation in real high-voltage windings using transfer function method," Electric Power Applications, IET, vol. 4, pp. 451-461, 2010.

[27] M.R.Barzegaran, "Detecting the Position of Winding Short Circuit Faults in Transformer using High Frequency Analysis," European Journal of Scientific Research ISSN 1450-216X Vol.23 No.4 (2008), pp.644-658, 2008

[28]N. Abeywickrama, Y. V. Serdyuk, and S. M. Gubanski, "Effect of Core Magnetization on Frequency Response Analysis (FRA) of Power Transformers," Power Delivery, IEEE Transactions on, vol. 23, pp. 14321438,2008

[29]J. Chong and A. Abu-Siada, "A novel algorithm to detect internal transformer faults," in Power and Energy Society General Meeting, 2011 IEEE, 2011, pp. 1-5.

[30]J. Bak-Jensen, B. Bak-Jensen, and S. D. Mikkelsen, "Detection of faults and ageing phenomena in transformers by transfer functions," Power Delivery, IEEE Transactions on, vol. 10, pp. 308-314, 1995.

[31]K. Pourhossein, G. B. Gharehpetian, and E. Rahimpour, "Buckling severity diagnosis in power transformer windings using Euclidean Distance classifier," in Electrical Engineering (ICEE), 2011 19th Iranian Conference on, 2011, pp. 1-1.

[32]W. H. Tang, A. Shintemirov, and Q. H. Wu, "Detection of minor winding deformation fault in high frequency range for power transformer," in Power and Energy Society General Meeting, 2010 IEEE, 2010, pp. 1-6.

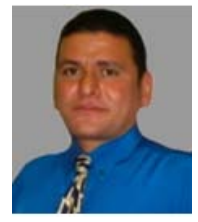

A. Abu-Siada (M’07, SM'12) received his B.Sc. and M.Sc degrees from Ain Shams University, Egypt and the $\mathrm{PhD}$ degree from Curtin University, Australia, all in Electrical Engineering. Currently he is a Senior Lecturer in the Department of Electrical and Computer Engineering at Curtin University. His research interests include power system stability, condition monitoring, power electronics and power quality. He is Editor-in-Chief of the international journal Electrical and Electronic Engineering, a regular reviewer for IEEE Transactions on Dielectrics and Electrical Insulation, Power Electronics and Sustainable Energy. He is the vice-chair of the IEEE Computation Intellegence Society, WA Chapter.

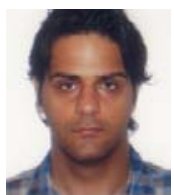

N. Hashemnia received BSc in Electrical Power Engineering from Yazd University, Iran in 2006 and Master of Electrical Utility Engineering from Curtin University in 2010. He received a scholarship from the Cooperative Research Centre for Infrastructure and Asset Management in August 2011, to enable him to pursue his $\mathrm{PhD}$ study at Curtin University. His research interests include power transformer condition monitoring and application of artificial intelligence to power systems.

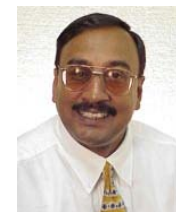

S. Islam (M’83, SM’93) received the B.Sc. from Bangladesh University of Engineering and Technology, Bangladesh, and the M.Sc. and PhD degrees from King Fahd University of Petroleum and Minerals, Saudi Arabia, all in electrical power engineering, in 1979, 1983, and 1988 respectively. He is currently the Chair Professor in Electrical Power Engineering at Curtin University, Australia. He received the IEEE T 
Burke Haye Faculty Recognition award in 2000. His research interests are in condition monitoring of transformers, wind energy conversion and power systems. He is a regular reviewer for the IEEE Transactions on Energy Conversion, Power Systems and Power Delivery. Prof. Islam is an Editor of the IEEE Transaction on Sustainable Energy.

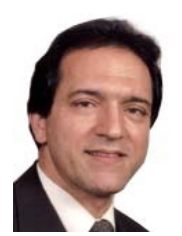

Mohammad A. S. Masoum (S'88-M'91-SM'05) received his B.S., M.S. and Ph.D. degrees in Electrical and Computer Engineering in 1983, 1985, and 1991, respectively, from the University of Colorado, USA. Dr. Masoum's research interests include optimization, power quality and stability of power systems/electric machines and distributed generation. Currently, he is a Professor and the Discipline Leader and Course Coordinator for Power System Engineering in the Electrical and Computer Engineering Department, Curtin University, Australia. He is the coauthor of Power Quality in Power Systems and Electrical Machines (Elsevier, 2008) and Power Conversion of Renewable Energy Systems (Springer, 2011). Dr. Masoum is Editor-in-Chief for the American Journal of Engineering and Applied Science, and an editor of the Australian Journal of Electrical \& Electronic Engineering. 